\title{
“Felicior si Augusto et Traiano melior" De Trajano a Teodosio, LA CONTINUIDAD DEL PRESTIGIO DE LA DINASTÍA UlPIA-AELIA*
}

\author{
"Felicior si Augusto et Traiano Melior" From Trajano to Teodosio, the \\ continuity of the prestige of the Ulpia-Aelia dynasty
}

JaVier Verdugo SAntos Junta de Andalucía

Recibido: 06/09/2017

Revisado: 23/05/2018
Aceptado: $31 / 05 / 2018$

Publicado: 29/06/2018

\section{RESUMEN}

El presente trabajo pretende realizar una aproximación al estudio de la imagen que Trajano proyecta no solo entre sus contemporáneos o sucesores directos, muy analizada por los historiadores del mundo antiguo, sino sobre los emperadores posteriores, como es el caso de Decio quien adopta por decisión del Senado el cognomen de Traianus, Constantino con los spolia trajaneos en su Arco del Foro, Juliano o Teodosio y Arcadio. Estos últimos erigirán en Constantinopla sendas columnas coclidias a imagen y semejanza de la columna de Trajano, a cuya estirpe hispana pretenden identificarse, asumiendo así la continuidad del prestigio Ulpio-Aelio en sus propias acciones buscando la auctoritas con el pasado.

\section{ABSTRACT}

This paper aims to make an approach to the study of the image Trajano projects not only among his contemporaries or immediate successors, very analyzed by historians of the ancient world, but on the later emperors, as in the case of Decius adopter decision Senate cognomen of Trajan, Constantine with trajaneos spolia in the Arco Forum, Juliano or Theodosius and Arcadius. The latter erected in Constantinople paths coclidias columns image and likeness of Trajan's column, whose aim Hispanic lineage identified, thus assuming the continuity of Ulpio-Aelio prestige in their own actions seeking auctoritas with the past.

\section{Palabras Clave}

Trajano; Teodosio; Arcadio; Columnas; Prestigio; Pasado.

\section{KEY WORDS} Past.
Trajan; Theodosius; Arcadio; Columns; Prestige;

* En el 1900 aniversario de su consecratio

fjavier.verdugo@juntadeandalucia.es 


\section{TRAJANO. OPTIMUS PRINCEPS}

La llegada al poder de Marco Ulpio Trajano (figura 1), tras su adopción por Nerva1, supone la continuación de la regeneración del orden institucional, iniciada brevemente por aquel, tras el reinado de Domiciano. Con él se inaugura la dinastía UlpiaAelia, que será ejemplo en el futuro². En el 114, el Senado le concede la dignidad de Optimus Princeps, asociándose así a la figura de Júpiter como vemos reflejado en el Arco de Benevento, erigido entre 114 y 117 (figura 2) y en algunas acuñaciones (Figura3).

Con Trajano se configura la idea de príncipe ideal, justo y piadoso comparable nada menos que con Augusto. El Panegírico de Plinio el Joven (López Cañete, 2003) será la pieza política de su principado $^{3}$, que inaugura una nueva edad de oro, con un

1 Tras la llegada al trono imperial, como consecuencia del derrocamiento y asesinato de Domiciano, Nerva (96-98), reputado y anciano senador, sin experiencia militar, adoptó como hijo y sucesor a M. Ulpio Trajano (Italica 18 de septiembre del 53 - Selinunte o Selinous 9 de agosto del 117), a quien el Senado concedió el título de César Augusto Germánico, el imperium proconsular y la potestad tribunicia. Esta adopción debió ser consecuencia del clan hispano, con L. Licinio Sura a la cabeza que era un potente "lobby" en los ámbitos políticos de Roma. A este respecto véase Bennett (1997, 43-54), Canto (1991, 277-234; 1998, 209-224; 2003a, 263-305) y López Barja \& Lomas Salmonte (2004: 387). Sobre las raíces béticas de Trajano y el origen turdetano de su familia véase Canto (2003b). El emperador Nerva murió en el 98, año de la adopción de Trajano, accediendo éste al trono imperial.

2 Seguimos la propuesta de la profesora Canto (2006, 401-402) de reivindicar la denominación de dinastía UlpiaAelia frente a la "dinastía antonina" y "emperadores antoninos", que en su opinión responde a una construcción sesgada e intencionada para minusvalorar el origen hispano de los mejores emperadores de Roma, cuando las propias fuentes antiguas hablan de Ulpia progenies (Claud., de IV cons. Honorii v. 17-18, 398 d.C.: Ulpia progenies et quae diademata mundo sparsit Ribera domus), Proles Aelia (Claud., de VI cons. Honorii v. 420: Hic proles atauum deducens Aelia Neruam ...) o Serie Aelia (Claud., Laus Serenae (carm.min. XXX) v. 55-56: ... Tibi (Hispaniae) saecula debent Traianum, series his fontibus Aelia fluxit.

3 Hidalgo (1995) analiza la evolución del concepto de poder imperial, la Basilieia romana, sobre el que confluyen fuertes influencias orientales y helenísticas que producen, en su aplicación práctica, determinados desencuentros como ocurre en los principados de Calígula y Nerón, en clara oposición a la casta senatorial, o son usadas de forma moderada por Augusto y muy óptimas con los Ulpio-Aelios, tanto por Trajano, como por Adriano y Marco Aurelio. La evolución del concepto parte de la idea del Princeps elaborado en época augustea y que nos transmite la imagen del "me-
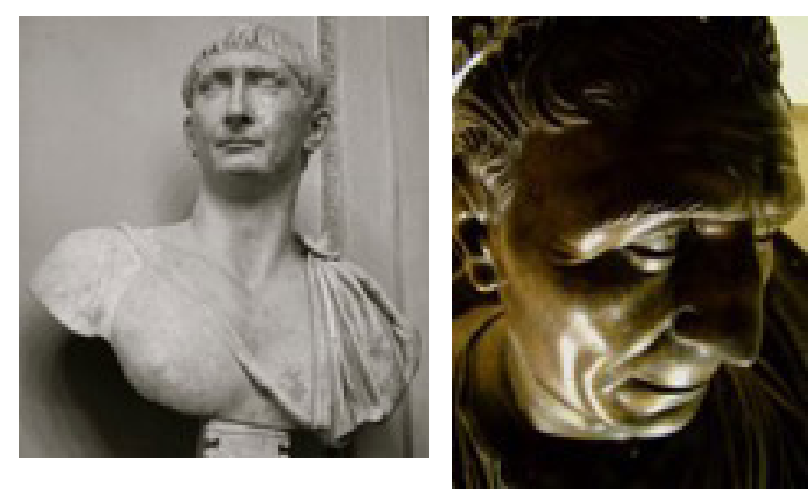

Fig. 1. Izquierda, busto de Trajano del 108 en la decennalia de su ascenso al trono. Imagen de cierta altanería (García Bellido, 1972: 359) a sus 45 años () Musei Capitolini. Roma. Derecha, detalle del clypeo de bronce con el semblante de un Trajano ya viejo, que transmite una imagen de naturalidad y pesadumbre tras tantos años de gobierno. Museum of Anatolian Civilizations. Ankara () Wikimedia Commons. Bjorn Christian Tornissen, 29 de julio de 2009.

emperador justo que aparece rodeado por mujeres ejemplares (Hidalgo, 2012, 111-121. Posadas, 19961997, 173-179). Todo ello producirá una tradición en cronistas posteriores, como es el caso de Eutropio (Brev., VIII, 5.3) que recoge la salutación de los emperadores por el Senado, cuando les decían más de 300 años después: Felicior si Augusto et Traiano melior (iQue seas más feliz que Augusto y más prudente que Trajano!), como si para ellos aquellos césares fuesen sus contemporáneos ${ }^{4}$. Desde el pun-

jor de los ciudadanos" elegido por la divinidad. Véase a este respecto Fustel de Coulanges $(1983,225)$ sobre la elección de los magistrados por los dioses en la República primitiva romana. Esta idea del princeps aparentemente un equilibrio republicano entre la nueva magistratura y las tradicionales como el consulado o la potestad tribunicia. Pero en realidad esto era mera apariencia pues en la práctica el poder se ejercía cada vez más de forma autocrática. Todo dependía de las cualidades morales y personales de quien ejercía como Princeps.

4 En el interés de los romanos por la Antigüedad, observamos la dificultad de definir los límites temporales de aquélla. En la obra de Tácito, De Oratoribus, un personaje hace una defensa de los "nuevo" como antítesis de lo "antiguo", cuestión ésta presente a todo lo largo de la obra, estimando que sólo pueden ser antiguos aquéllos que están alejados del presente más de mil años. Lo que situaría a Alejandro entre los "modernos" contemporáneos de Tácito. Sólo serían "antiguos" los héroes de Troya. Grecia será la nutriente de los romanos, pero los griegos serán considerados hombres modernos de los que apenas les separan unas pocas 
to de vista figurativo, un ejemplo revelador de esta concepción de la figura de Trajano es el Arco de Benevento, ya citado, que conmemora no acciones de guerra sino políticas benefactoras para el pueblo. Un arco pacífico que busca resaltar la providentia augusta. En uno de sus relieves se hace alusión a los alimenta, y aparecen representadas ciudades, el propio emperador y personas vinculadas a esta institución de ayuda a los huérfanos. En el otro relieve frontal a éste se representa un sacrificio al que asisten: el fortissimus princeps, como es llamado Trajano en la inscripción, acompañado del Senado y del Pueblo Romano. En los relieves del ático se escenifica la pacificación de las provincias fronterizas del Rin, Danubio y Mesopotamia.

Adquiere especial importancia por su alto significado, la ideoescena llamada "la abdicación de Júpiter" (figura 2), en el que el supremo dios cede simbólicamente su poder a Trajano, mediante la entrega de su cetro y su rayo. A dicho acto asisten Juno y Minerva y tras ellas Hércules, Liber Pater, Ceres y Mercurio (figura 2). Hay un hecho destacable que es la ausencia, en la representación del acto, de Trajano, que solo lo está en espíritu, para no convertir la alegoría en algo excesivamente ostentoso (García Bellido, 1972, 378). Todo el arco es una enorme alegoría al Buen Gobierno: recibimiento de Trajano en el Foro por el Senado y el Pueblo; retorno del emperador con sus lictores y equipo de gobierno y finalmente el acto de disposición de las leyes de los alimenta ${ }^{5}$, ante Italia, Marte, Ceres y la Fortuna.

Otro ejemplo de la pietas de Trajano es la divinización de Nerva. En relación a la cual tenemos el testimonio de Plinio el Joven (Paneg. 11): "Lo lloraste primero con las lágrimas, como corresponde a un hijo, luego con templos..."

generaciones. Es un mundo en el que la historia parece correr con una lentitud que no alcanzamos a veces a comprender. Por eso las comparaciones con personajes alejados de sus contemporáneos como si convivieran en un presente eterno, se nos antojan curiosas y difíciles de entender (Maravall, 1986, 120-130; Verdugo, 2015,7, Verdugo, 2017a, 203).

$5 \mathrm{La}$ importancia de los alimenta se ve expuesta también en un relieve del Foro republicano-anaglypha-, junto a los Rostra y en el que aparece el emperador instituyendo la institución puericultora.

6 Moreno Soldevilla (2010: 16, nota 94) recoge la opinión al respecto de Syme (1958: vol. I, 12) sobre la falta de testimonios sobre ningún templo. Aunque si de una inscripción, en la que se conmemora la pietas de Trajano (ILS 283).
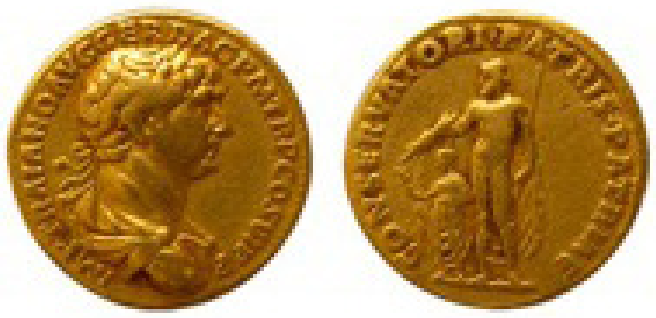

Fig. 3. Aureus de Trajano. Anverso: IMP TRAIANO AVG GER DAC PM TRP COS VII PP, busto laureado hacia la derecha. Reverso: aparece el emperador con toga y rama de laurel en la mano bajo la protección de Júpiter, quien sostiene el cetro y el rayo con la leyenda: CONSERVATORI PATRIS PATRIAE (BMRC, 493), según Mattingly (1976; plate LXXII, cit. Montero, 2000,60 , nota 40 ) se acuñó para conmemorar la salvación milagrosa de Trajano en el terremoto de Antioquía, en diciembre de 115 , donde "un ente, de estatura mayor que la humana, llegó hacia él y le llevo afuera, de forma que sólo sufrió leves daños". Para Montero (2000, 62) Trajano porta una rama de laurel referencia a la ceremonia lustratoria que se celebró en la ciudad por espacio de treinta días y en las que se quemaron hojas de laurel e incienso.

Plinio el Joven, en su discurso laudatorio impregnado del lenguaje habitual de los panegíricos, evidentemente desmesurado, nos aporta, sin embargo, algunas claves sobre la opinión de los romanos occidentales sobre las divinizaciones en la que se deja entrever como para éstos dichas prácticas 

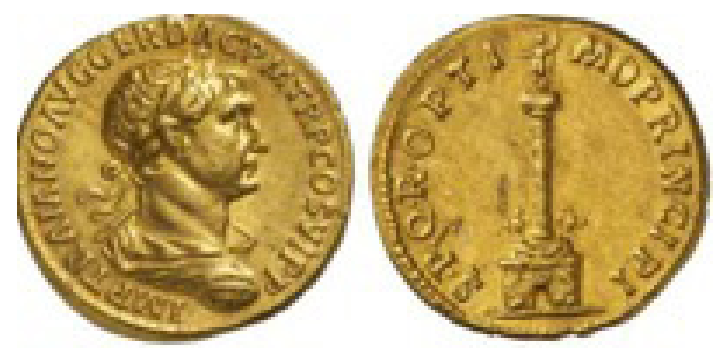

Fig. 4. Aureus. Anverso: IMP TRAIANO AVG GER DAC PM TRP COSVI PP - Busto de Trajano laureado vuelto hacia la derecha. Reverso: SPQR OPTIMO PRINCIPI, con la Columna y dos lechuzas.

eran aún, en fecha tan avanzada, objeto de cierta crítica sobre los excesos de los príncipes. Así (Plin. Paneg. 11, 2-3) dice: "Tú elevaste a tu padre ${ }^{7}$ a las estrellas, no por provocar miedo en los ciudadanos, no para agraviar a los dioses, no para que redundase en honor tuyo, sino porque crees que es un dios. Esto tiene menos valor cuando lo hacen quienes se consideran dioses también ellos". El panegirista (Plin. Paneg. 11, 4-5) también critica a los que se consideran dioses en vida o que se presentan como tal aprovechándose de la divinización de sus antepasados lo que considera tan farsante como los generales que celebran falsos triunfos y ponen de manifiesto su cobardía (Moreno Soldevilla, 2010, 17, nota 100). A pesar de estos elogios, Trajano también consintió ciertos honores divinos en vida. Ya hemos visto la abdicación de Júpiter del Arco de Benevento muy en consonancia con su aceptación en el 114 del título de Optimus que lo acercaba a Iupiter Optimus Maximus. Incluso su decisión de enterrarse dentro de la ciudad en su columna (figura 4) en la que se narra sus hazañas en la Dacia también debe ponerse en relación con esa consideración divina (Settis, 1984, 68-104; Settis, 1988, 5-248) y La Regina (1997, 117-135). En el estudio que realiza Arce (1998, 55-69) sobre la muerte, consecratio y triunfo de Trajano manifiesta que la tumba de Trajano fue inusual, y no cabe el argumento de que la misma respondiese a la necesidad de espacio en el tumulum Iuliorum, pues Nerva se había enterra-

7 Además de Nerva, Trajano también divinizó a su padre natural en el 112. Plinio el Joven (Plin. Paneg. 89, 2), dice a Trajano padre: pero también tú, Trajano padre [...] si no en las estrellas, tienes una sede cercana a las estrellas. Sobre la figura de Trajano padre véase a G. Alföldy (2000). do allí, y luego lo hará Julia Donna en época severiana.

La cuestión responde mucho a más al deseo del propio emperador de tener su tumba dentro del pomerium algo que ya habían hecho los Flavios en su Templum Gentis Flaviae ${ }^{8}$, enfatizando así con su programa de Foro-tumba la idea greco-helenística del héroe fundador -ktistes- que se entierra en la ciudad, preparándose además una tumba propia de un triumphator, pues así se consideraba el mismo después de sus victorias en la Dacia. En este monumento conmemorativo a la victoria, el princeps será enterrado como un dios, tras su consecratio (figura 4), honores que no fueron puestos en duda por el Senado, quien otorgó incluso más de los solicitados por Adriano. Trajano, no sólo se representaba en las escenas de la columna, sino que también colocaba una estatua en todo lo alto. Se hacía enterrar en ella, - tumba y triunfo- y dedicaba dos bibliotecas a cada lado de la columna, con una simbología clara, la historia de los romanos estaba en los libros, además de en esta narración en piedra. En distintas monedas en las que se representa el monumento (figura 3), aparecen dos lechuzas, que en opinión de Settis (1988, 58-59) deben hacer referencia a las dos bibliotecas adyacentes, al ser la lechuza un atributo de la sabiduría de Atenea o de Minerva. Settis $(1988,67)$, considera que el conjunto biblioteca-columna, coronado por la estatua de Trajano, el cual es representado, casi sesenta veces en acción en el dinámico friso, persigue tres funciones: la "indicativa”, representada por la inscripción; la "honoraria", tipología y friso, y la "funeraria", con la cámara del basamento, además de celebrar también la "sabiduría" del emperador: sapientia Augusti.

La biblioteca Ulpia debió tener anexo un laboratorio de copias y de enmendatio de textos, como lo atestigua una información al respecto del siglo IV que habla de ello in schola Fori Traiani, y la actividad del gramático Bonifacio, que en su ins-

8 En realidad, aunque la Lex Duodecim Tabularum prohibía los enterramientos dentro de la ciudad: Hominem mortuum in urbe ne sepelito neve urito, hubo también algunas excepciones como nos cuenta Cicerón (De leg., II. XXII.58). Son los clari viri, los héroes, a los que la República concedía el honor-virtutis causa- de ser enterrados dentro de la ciudad: Publio Valerio Poplícola, Publio Postumio Tuberto o Cayo Fabricio Luscino. Para ello, como afirma Arce $(1988,88)$ se requería autorización del Senado, y no respondía a una decisión personal. Así en el caso de Trajano esta decisión responde a un concepto autocrático del poder. 
cripción sepulcral (IV-V siglos) se refiere a los atria Traiani (Marrou, 1932, 93-110). La biblioteca debía tener esculturas de autores relevantes de la literatura griega y latina, y naturalmente de Atenea.

Trajano con su conjunto Columna-Bibliotecas, sigue una tradición romana, que es expuesta por Settis $(1988,67)$, relativa a que muchos grandes hombres quisieron dejar memoria de ellos a través de la fundación de una biblioteca: Pantainos en Atenas, Caio Manilio en Bolsena o Plinio en Como (Plinio el Joven, I, 8, 6). Sobre todos ellos sobresale, el testamento de Tiberio Julio Celso Polemeano, contemporáneo de Trajano -senador romano, cónsul en el 92 y procónsul de Asia entre el 105 y el 106-, que comenzó a construir una biblioteca, que terminará su hijo: Caio Julio Aquila -consul suffectus en el 110- y los herederos de éste. En su testamento, asigna a la biblioteca, libros, y una renta anual que sirviese al mantenimiento y al incremento de nuevos fondos; hasta aquí no se distingue de sus predecesores, si no fuese por la circunstancia de que Celso, disponga qué bajo la sala dispuesta con tres órdenes, con armarios y anaqueles, y galerías de madera, se coloque una cella funeraria, en la que se ha encontrado su sarcófago. Biblioteca y tumba aparecen unidos, muerte y sapientia con un nexo estrechísimo. La intención de Trajano es idéntica a la de Celso, su deseo de unir su tumba a una biblioteca, colocándola cerca del Foro, como Celso junto al ágora; el oferente de Celso su hijo, el de Trajano, el Senado. En ambos casos la finalidad es funeraria, y solo se hace explicita post mortem. (Settis, 1988, 69-70).

Debemos referirnos a otro episodio digno de consideración para entender la ideología de Trajano dirigida a institucionalizar una nueva era, nos referimos a la divinización de las mujeres de su familia, cuestión que debe ponerse en relación, siguiendo a Posadas (1996-1997), con la imagen de integridad moral que Trajano y su círculo intelectual: Plinio y Tácito entre otros, deseaban imprimir al nuevo Saeculum que se diferenciaba de la etapa de denigración de los julio-claudios y de Domiciano. Un deseo de restituir las viejas costumbres del que es expresión la llamada a que las madres críen a sus hijos $^{9}$ o la institución de los alimenta en apoyo de los huérfanos. Las mujeres de Trajano son tachadas

9 Se pretendía con ello preservar la lengua latina, pues las nodrizas eran casi todas extranjeras y las virtudes romanas que debían ser transmitidas por los padres. de virtuosas y púdicas y forman una familia ejemplar y modélica. La primera en ser divinizada fue la hermana de Trajano: Ulpia Marciana (figura 5), viuda de C. Salonius Matidius Patruinus, muerto en el 78, y que era un ejemplo de univira, lo que implicaba un notable ejemplo de moralidad. Ulpia había rechazado ser nombrada Augusta, pero finalmente lo aceptó en el 105, murió en el 112 y a los tres días de su funus fue objeto de su consecratio y declarada Diva Marciana. Ulpia tuvo una hija, Salonia Matidia (figura 6) - Matidia Maior- madre de Vibia Sabina, futura esposa de Adriano. Matidia, asumió el título de Augusta a la muerte de su madre en el 112, y a su muerte fue divinizada por su yerno. Pero quizá el caso más ejemplar sea la divinización de Pompeia Plotina (figurra 7), esposa de Trajano, quien había sido honrada con el título de Augusta en el 105, en el mismo año que su cuñada Marciana. A su muerte en el 122 fue divinizada. Así en dos reinados, el de Trajano y el de Adriano, se producen nada menos que tres divinizaciones de mujeres, de las que solo una era esposa de un princeps, algo excepcional desde Livia, la última de las mujeres divinizadas. El caso de Plotina es además un modelo de elección de esposa. Plinio (Plin. Paneg. 83, 4) hace una descripción del carácter de la emperatriz que se convierte en una alabanza del propio Trajano, pues éste ha sabido elegir una esposa virtuosa "a la antigua”, sencilla en su aspecto, modesta en sus andares (Plin. Paneg. 83,7). Y termina, y esto es lo más resaltable (Posadas, 1996-1997, 175), afirmando que todas las virtudes de Plotina se deben a Trajano que la ha educado en que "a una esposa le basta con la gloria de obedecer", y servir de ornato al marido.

A la muerte de Trajano, en Selinunte o Selinous el 9 de agosto del 117, Adriano, cuenta Spartiano (Vit. Had., VI, 687): "Por medio de una carta, por cierto, atildadísima, pidió al Senado, y consiguió por decisión unánime, que se le otorgaran a Trajano honores divinos. Incluso logró que el Senado, por su cuenta, tomara otras decisiones honoríficas respecto a Trajano, sin haberlas pedido él”. Siguiendo a Arce (1998, 61-69) Adriano debió asistir al acto de cremación del cadáver con un más que probable funus militar. Después las cenizas de Trajano fueron trasladadas, en compañía de Plotina y Matidia por mar, arribando a Roma a finales de septiembre del 117. El Senado celebraría una traslatio y otro funus que culminaría con el depósito de sus cenizas en urna de oro en la cámara de la Columna Trajana. En este momento debió 

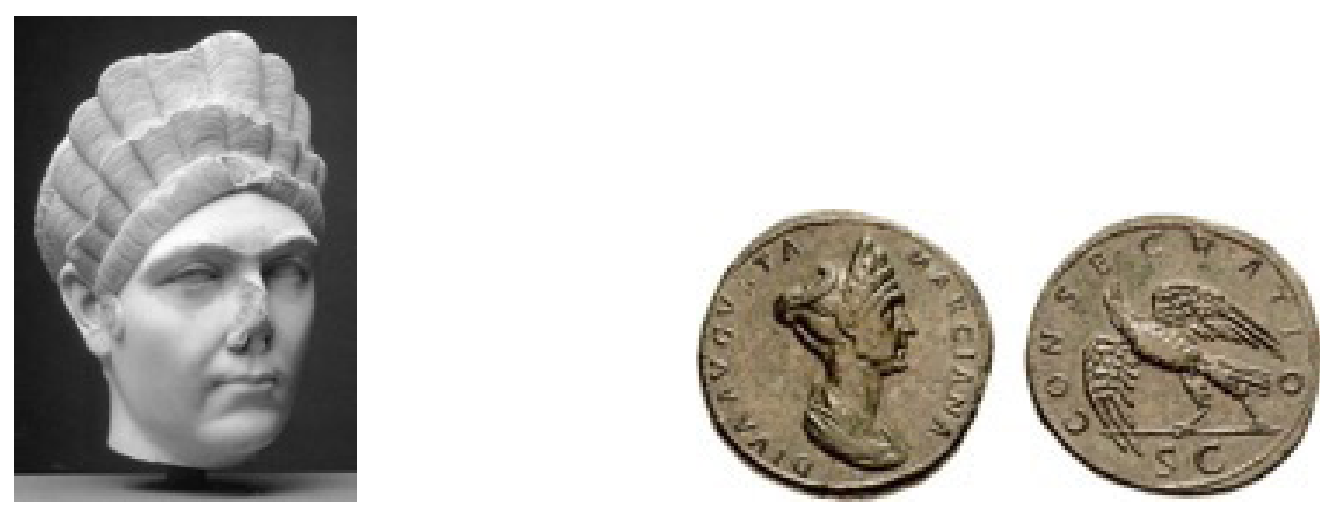

Fig. 5. A la izquierda busto de Ulpia Marciana. Metropolitan Museum of Art. New York @ Metropolitan Museum. A la derecha sestertius de Marciana, ca. 112 d. C. Anverso: DIVA AVGVSTA MARCIANA, busto con diadema hacia la derecha. Reverso: CONSECRATIO S-C, águila con cabeza hacia la derecha y las alas desplegadas.
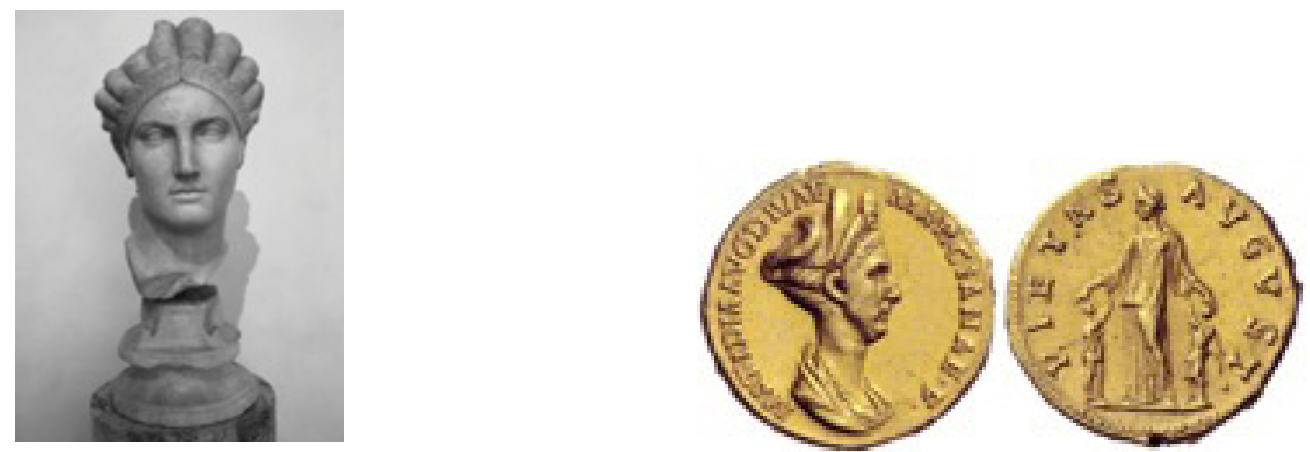

Fig. 6. A la izquierda, retrato colosal de Matidia, mármol de Luni, ca. 112-117. Musei Capitolini. Palazzo dei Conservatori. Inv. № MC 889. Roma ( ) MS. S. Sosnouskly (2005). A la derecha, aureus, 112-117. Anverso: MATIDIA AVG DIVAE - MARCIANAE F, busto drapeado de Matidia, que luce un collar y doble corona o diadema y el cabello con peinado muy elaborado. Reverso: PIETAS - AVGVST. La Pietas con diadema y vestido drapeado, de pie con la cabeza vuelta en acción de proteger a Matidia Minor y a Sabina que aparecen de pie a cada lado de la diosa levantando las manos hacia ella.
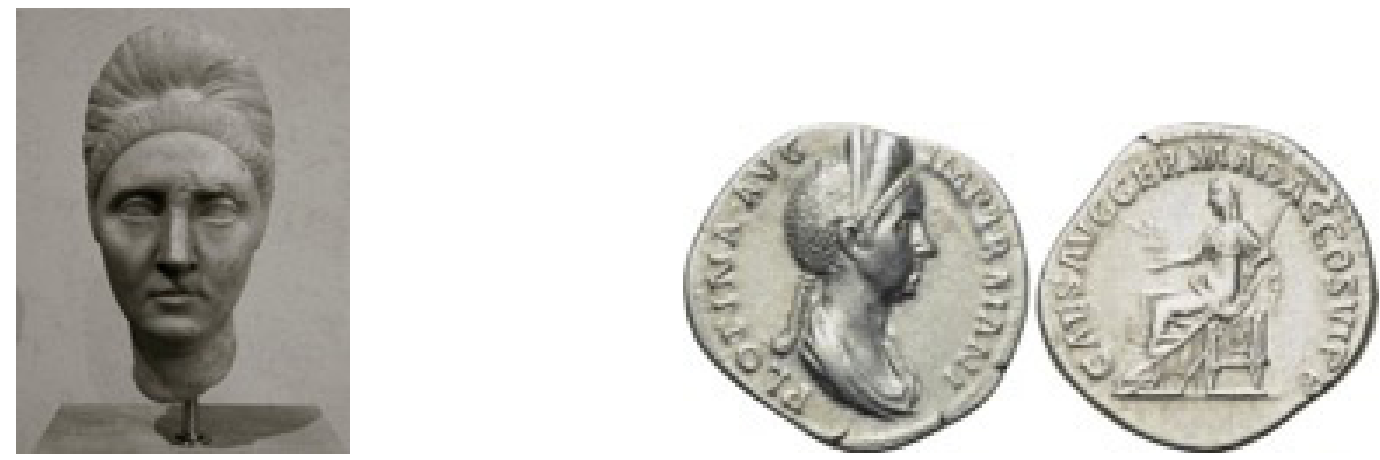

Fig. 7. A la izquierda, busto de Plotina. Marmol, ca. 110-120 d.C. Museo Nazionale Romano. Palazzo Massimo alle Terme In. № 339 @ MSNR. S. Sosnouskly (2005). A la izquierda dos denarios de Roma. El primero con anverso: PLOTINA AVG IMP TRAIANI, con busto de la emperatriz hacia la derecha drapeado y con diadema y reverso: CAES AVGG GERM DAC COS VI, con Vesta sentada hacia la izquierda portando el Palladium y un cetro, ca. 105-122. El segundo con anverso: PLOTINA AVG IMP TRAIANI, con el busto de la emperatriz hacia la derecha similar al anterior y reverso: CAES AVG GERM DAC COS VI PP - ARA PUDIC y altar con relieve de la Pudicitia, ca. 114-117 d. C. 
otorgarse el decreto de divinización. Adriano no volvió a Roma hasta el 118, habiendo permanecido todo el año anterior en Siria. Celebró con gran pompa el llamado triumphus partichus decretado por el Senado, en realidad un funus imaginarium con honores triunfales para la estatua de Trajano acompañada por Adriano, y que seguramente fue quemada in effigie certificando la divinización y el ius triumphalis concedido a Trajano (Arce, 1998, 68-69). También acuñó Adriano en el 117 un aureus (figura 8 ) en cuyo reverso no hizo representar, como era tradicional, un águila, sino el ave Fénix (Camozzi, 1901,12-26; Broek, 1971, 245-246), en una clara aceptación de este símbolo de influencia oriental, que nos adelanta el orientalismo de Adriano, relacionado directamente con la resurrección. Esta imagen se nos antoja especialmente recurrente, pues Trajano fue "resucitado" - como Ave Fénix- por intercesión de Gregorio Magno ${ }^{10}$, por sus virtudes, y poder entrar en el Purgatorio, donde lo encontrará Dante ${ }^{11}$.

Adriano honró finalmente a Trajano concluyendo el gran templo de aquél en Pérgamo, el llamado Traianeum y construyó otro en Italica ${ }^{12}$ (León

10 Trajano había tenido un comportamiento ejemplar con los cristianos y la "Leyenda de la Viuda" y su fama de justo, le había supuesto ser salvado del Purgatorio por Gregorio Magno, siendo "resucitado" para recibir la comunión (Gil, 2000, 2003a, 2003b). Fue un ejemplo como modelo de Justicia, y su iconografía con la viuda aparece recogida en tapices, arcos de triunfo y arcas nupciales como la elaborada por Mantegna para Paola Gonzaga (Verdugo, 2017b: 62 , nota 14). Este sentir sobre el emperador convertía su columna en un símbolo para los romanos, en un monumento cargado de intención patriótica, que Sixto V (1585-1590) quiso aprovechar para ponerla al servicio de la Iglesia (Verdugo, 2017b).

11 Dante hace dos referencias a Trajano, la primera (Purg. X. 73-76) cuando, en compañía de Virgilio llega a la primera cornisa de la soberbia del Purgatorio, y observa que tras una escena en mármol donde se representaba un carro que portaba el Arca de la Alianza, veíase otra en la que "se historiaba la alta gloria de aquel ilustre emperador romano para quien consiguió su victoria Gregorio: de quien digo es de Trajano y una viuda, entre lágrimas y lamentos, sujetábale el freno con la mano" quien le solicita justicia por la muerte de su hijo. La otra referencia se desarrolla en el Paraíso (Par. XX. 43-48; 100-102) en el Sexto cielo o Cielo de Júpiter, donde se encuentran los príncipes sabios y justos. Allí el Águila, símbolo del Imperio, manifiesta al poeta la existencia de almas que suponiéndose paganas, tenían su lugar en el cielo por haber muerto en la fe de Cristo, entre las que se encontraba Trajano, por su justicia a la viuda.

12 Cortés Copete $(2010,583-596)$ ha sugerido que el lla-

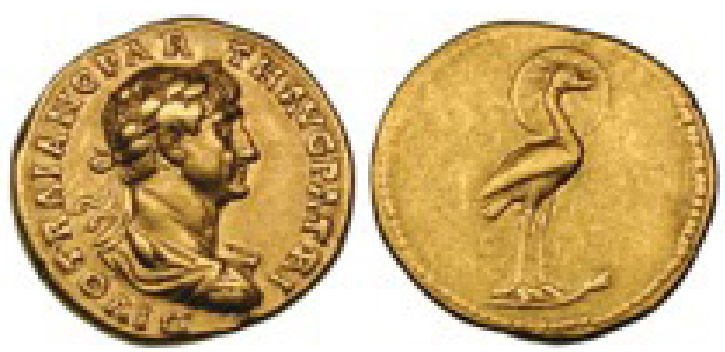

Fig. 8. Aureus del 118 acuñado por Adriano en Roma. Anverso: DIVO TRAIANO PAR TH AVG PATRI, con busto de Trajano laureado vuelto hacia la derecha. Reverso: Ave Phoenix con nimbo apoyando sus patas sobre una rama de laurel (C) dominio público.

1988), la patria de ambos, dentro del programa de renovación de la ciudad tras su declaración como colonia.

\section{TRAJANO Y LOS CRISTIANOS}

Uno de los testimonios (Teja, 1990, 2000, 477, Moreno Soldevilla, 2015 y González Fernández, 2003, 13-75) más antiguos que se poseen de escritores paganos sobre los cristianos es la Epistola X.96 de Plinio el Joven a Trajano y la respuesta de éste por medio de un rescriptum; y las opiniones de Tácito (Ann. 15, 44.2-5) y Suetonio (Ner.16.2). Tácito y Plinio eran senadores y Suetonio pertenecía al orden ecuestre, los tres por tanto son ejemplos de lo que debía ser la opinión dominante entre los sectores de mayor importancia económica y política del Imperio, y naturalmente del mismo emperador Trajano. Para ellos el cristianismo no es una religio sino una superstitio, y es calificado de la peor manera: superstitionem pravam et immodicam (Plin. Epis. X.96.8), exitiabilis (Tac. Ann. 15.44.2) y malefica et nova (Suet. Ner.16.2). Estos autores

mado Traianeum de Italica no se trataría de una obra de reconocimiento de Adriano a Trajano inspirado en el de Pérgamo y destinado a exaltar la relación dinástica sino que debe inscribirse en su acercamiento a la figura de Augusto -Hadrianus Augustus- y a la erección de un templo dedicado al culto imperial en el que el Genio de la Colonia de Italica sería el mismo Adriano, y que al igual que hizo en Pérgamo en cuyo Traianeum había sendas estatuas colosales de Trajano y Adriano y otra sedente de Zeus Olímpico, en Italica organizaría un templo similar, en el que además, como hizo en Tarraco y otras ciudades de Occidente, rendiría culto a Augusto, la Dea Roma y la Victoria Augusta. Véase en este sentido Blanco Frejeiro (1988, 103-107) en relación con la dedicatoria de una estatua a la Victoria Augusta por Vibia Modesta en dicho lugar. 
dan información sobre los cristianos no sólo de su época, sino también de hechos anteriores, en especial de los acontecimientos del principado de Nerón. Así Suetonio, como ya hemos dicho, dice que Nerón "persiguió a los cristianos, linaje de hombres entregados a una superstición nueva y maléfica"’3.

En este contexto hay que situar la carta de Plinio el Joven a Trajano, en su calidad de gobernador senatorial de la nada tranquila provincia de BitiniaPonto. La carta se fecha en el otoño-invierno del 110-111 o del 112-113. Plinio, inexperto en el gobierno, comienza afirmando que no había tenido ocasión de intervenir en procesos - cognitiones- contra los cristianos, y aunque es consciente de que los cristianos deben ser sancionados no acierta a saber cuál debe ser exactamente la acusación contra ellos. La primera conclusión es que no existía ninguna legislación general contra los cristianos y sus actividades. También es prueba, como afirma Teja $(1993,192)$, de que los cristianos no entrañaban un peligro grave para el sistema, ni tampoco constituían una preocupación en la mente de Trajano, al igual que en la de sus antecesores. En los siglos I y II, el fenómeno cristiano no preocupó al orden público romano, y la persecución puntual de Nerón, debemos incluirla entre las numerosas extravagancias del príncipe o simplemente en la represión y castigo a los autores del incendio de Roma, que pudo ser responsabilidad de un grupo de fanáticos, entre los que existiese algún cristiano (Fini, 2003,174). También la persecución de Domiciano, no parece del todo cierta. Según parece, Plinio, llevaba el encargo de Trajano de contrarrestar la influencia de las asociaciones - hetaeriae- que producían constantes alteraciones de orden público, por sus actitudes políticas subversivas (Plin. Epis. X, 33), y fue por tanto en este contexto donde se topó con el problema cristiano.

La opinión de Plinio el Joven hacia aquellos era idéntica de la de Tácito y Suetonio, para él los cristianos merecían ser castigados por ser una superstición malvada y desmesurada: nihil aliud inveni quam superstitionem pravam et inmodicam (Teja, 1993, 194). Con las primeras actuaciones de Plinio sobre los cristianos, comenzaron a incrementarse las acusaciones muchas de ellas basadas solo en odios personales y venganzas, o en intereses económicos, como la llevada a cabo por los carniceros que habían visto reducidas sus ventas por la

13 afflictis suppliciis Christiani, genus hominum superstitionis novae ac maleficae. negativa de los cristianos a comer carne de animales sacrificados a los dioses, lo que indica que los cristianos eran ya una comunidad muy extensa en Bitinia ${ }^{14}$. Por tales hechos, y ante la preocupación de Plinio el Joven de que la represión excesiva pudiera ser contraproducente para la paz, solicita consejo al emperador. Debe tenerse en cuenta, además, que los cristianos habían obedecido el edicto prohibiendo las hetaeriae y habían dejado de reunirse y que se había comprobado por los agentes de Plinio el Joven que eran falsas las calumnias sobre sus ritos abominables.

El emperador contesta con su célebre rescripto ${ }^{15}$, que en opinión de Teja $(1993,195)$ es un modelo de oportunismo y tacto político. Concluye diciendo que no debe irse al castigo de los cristianos como tales, salvo que exista una acusación en forma y probada, en cuyo caso deben ser castigados. Así mismo, potencia el arrepentimiento, política que el propio Plinio el Joven le había sugerido, proponiendo el perdón para los que lo hicieran de forma manifiesta, esto es sacrificando a los dioses. Rechaza que se de crédito alguno a los libelos: "pues es una práctica abominable que no es propia de nuestros tiempos”.

El rescripto de Trajano es la primera respuesta de un emperador al problema cristiano que conocemos, lo que no significa que sea el primero en el tiempo. Sabemos por Lactancio (Div. Inst. V, 11, 19), que Ulpiano, siglo III, había recopilado en su tratado De officio proconsulis todos los rescriptos

14 Estos episodios se daban desde fechas muy tempranas como el de la "Revuelta de los orfebres" de Éfeso, en época de Pablo de Tarso, recogido en los Hechos de los Apóstoles (V. 19.23-28 y V. 20.1) artesanos, que ven peligrar su industria, ligada a los visitantes del famoso santuario de Artemisa, por considerar las predicaciones cristianas como un ataque a sus principios religiosos y a la imagen de la propia ciudad, íntimamente ligada a Artemisa, y su santuario, en el que además se rendía culto imperial (Verdugo, 2011: 94). También sabemos por los Hechos de los Apóstoles (Hch. 18.12.17) que Pablo tuvo contacto, entre el 52-53, con Marco Anneo Novato, hermano de Séneca, conocido como Junio Galión, tras su adopción por J. Junio Gallio. Fue considerado uno de los personajes más fascinantes de la Antigüedad, bondadoso y justo, quien ante la acusación de los judíos de Corinto a Pablo por religio illicita, resolvió: “Judíos si se presentase una injusticia o un crimen admitiría yo vuestra querella. Pero no me meto en vuestras querellas religiosas, ni tengo ganas de ser juez de ellas" (Holzner, 2008: 269-271).

15 Una de las cuatro categorías de constituciones imperiales (edicta, decreta, rescripta y mandata), y se refiere a las respuestas que el príncipe daba a consultas planteadas por magistrados, funcionarios o particulares. 
imperiales que daban normas sobre los cristianos, pero no fueron recogidos por Justiniano en el $\mathrm{Di}$ gesto, y se han perdido (Teja, 1993, 196 y Vallejo, 1997, 217-228).

Según parece, Trajano pretendió introducir un elemento de racionalidad en el conflicto entre cristianos y el poder político, que venía obstaculizado por el fanatismo de algunos cristianos que buscaban en el martirio la vía rápida para el reino de Dios, y por los excesos de algunas autoridades locales, en las que influía el odio de la plebe hacia los cristianos, como ocurrió en Antioquia, cuando el 13 de diciembre del 115, tras un terremoto la gente culpó a los cristianos de haber levantado la ira de los dioses.

LA IMAGEN DE TRAJANO EN LA HISTORIOGRAFÍA ANTIGUA

González del Campo (2009,45-47) hace un recorrido sobre la utilización de Trajano como figura modélica por todos los historiadores tanto paganos como cristianos, especialmente, entre estos últimos, de este modo, Tertuliano (Apol. 5.7) lo incluye en la lista de los buenos emperadores y Lactancio (Mort. Pers. 3-4) no lo encuadra en la de los perseguidores y sino entre aquellos que tras Domiciano permitieron a la Iglesia expandirse (Mort. Pers. 3, 4-5). También en la Historia Augusta hay muchas referencias elogiosas de Trajano en especial en la llamada Vita Hadriani (A.5.4; 9.1; 21.10) en la que se establece el contraste entre Adriano y su predecesor especialmente en política exterior o en Lampridio (Sev. Alex, XLVIII); igualmente, diversos autores como Aurelio Victor (Caes. 13.13), Festo (Brev.14.3) o Eutropio (8.6.2) señalan que Adriano no era un gobernante a la altura de Trajano, añorándolo (Arce,2003).

En definitiva, Trajano es ejemplo de príncipe justo (Dion Casio, Historia romana, LXIX,6), recordemos que durante su gobierno Trajano introdujo importantes cambios en la administración provincial (González Román, 2000, 181-182) y Plinio (Paneg. 70, 7-8) nos habla de cómo el emperador valoraba la virtus de los gobernadores provinciales. En su reinado hubo un aumento de las acusaciones por repetundae ${ }^{16}$ (Bennett, 2001, 114,

16 Lex Iulia de pecunis repetundis del 59 a. C. establecía la prohibición de recibir donaciones a favor de los magistrados en el ejercicio de su cargo, ponía límite a los regalos y gratificaciones y regulaba los impuestos que podían imponerse a los provinciales, se incluían en ella los castigos que podían ir desde el exilio, el destierro a una isla o la pena
González Román, 2000, 180) en procónsules y legados en África, Bitinia y Egipto, y especialmente en la Bética destacando la llevada a cabo contra el gobernador Caecilius Classicus así como contra el procónsul Baebius Massa, detalles de estas acusaciones nos han sido proporcionados por Plinio (Ep.I,7, III,9, III, 9,17) debido a que participó como advocatus de los provinciales de la Bética. También sabemos que el propio Trajano debió tener un conocimiento directo del proceso de Classicus dado que se encontraba en Roma entre septiembre del 99 y marzo del 101, fechas entre las que debió llevarse a efecto el mismo (González Román, 2000, 199). También es significativo su sentido de la generosidad hacia los soldados cuando simplificó las formas del testamento militar. Trajano es el primer príncipe que tomó una medida al respecto por medio de una mandata principum (Labruna, 1962, cfr. Bialostosky, 1984, 315) recogida en el Digesto (29.1.pr.) que establece que los militares podían hacer sus testamentos "como quieran y como puedan", lo que permitía evadir el formalismo testamentario. Estas excepcionalidades fueron utilizadas por primera vez por los milites activos y veteranos de la $L e$ gio III Cyrenaica y por la XXII Deiotana que se encontraban acantonadas en Alejandría (D. 9.1.24). Esta reducción de formalismos de la mandata de Trajano, no suponía que el militar no pudiera en circunstancias normales otorgar un testamento según el ius commune al igual que cualquier otro ciudadano (D. 29.1.5), sino que venía a otorgar por criterios de la naturaleza de la vida militar - un "privilegio" que permitía eludir ciertas formas (D. 29.1.pr.; 9.1.24). Cuestión ésta que con el tiempo se convirtió casi en un derecho particular-ius singulare-frente al ius commune introduciéndose el codicilo (Codex 6.36.) y el fideicomiso (D.30.1; Codex 3.17$)$. En esta forma más abreviada se ha querido ver una concesión a la simplicitas militum (D.29.1.1; Gaio, II.104 y 109; Inst. 2.11; Codex 6.30, 22 pr.; D. 22.6.9.1 y D. 29.1.40.2) que consideraban al militar con una inteligencia poco preparada para las complejidades jurídicas (Bialostosky, 1984, 315316, nota 13). En cuanto a los motivos de estas disposiciones debemos atribuirlos, más que la falta de preparación jurídica de los soldados, tan común en el resto de la ciudadanía, a las razones ya comentadas de generosidad hacia un colectivo que aseguraba la paz lejos de sus hogares, en muchos casos.

capital (Dig. 48, 12, 7-8). 
Trajano, en vida y tras su muerte, comenzó a tejer a su alrededor una leyenda sobre sus virtudes y sentido de la Justicia, atribuyéndosele algunas anécdotas que no le correspondían como afirma Lampridio (Vit. Sev. Alex. XLVIII, 873) respecto al episodio del conspirador Ovinio Camilo, a quien Alejandro Severo, lejos de castigar, le hizo desistir tras mostrarle lo duro que era ser emperador, añade Lampridio: sé que el vulgo atribuye este episodio que he narrado a Trajano, pero ni Mario Máximo, ni Fabio Marcelo, ni Aurelio Vero, ni Stacio Valente, que culminaron su biografía completa, expresan esta anécdota en su vida..., esto demuestra la existencia de una tradición de atribuir a Trajano acciones de grandeza, sobre todo en comparación con su sucesor Adriano (G. París, 1878, 289). Esta fama del emperador llegó integra e incluso rodeada de misterio hasta la Edad Media, elaborándose su leyenda sobre su salvación del infierno por Gregorio Magno y la de Paladín de la Justicia, con el famoso episodio de la Viuda ya referido.

\section{LA TRASCENDENCIA DE TRAJANO EN LOS EMPERADO- RES POSTERIORES}

\section{El título de Traianus a Decio.-}

Uno de los ejemplos más interesantes de la perpetuación del prestigio trajaneo es el otorgamiento por el Senado al emperador Gaio Messio Quinto Decio $^{17}$ (249-251 d.C.) del título de Traianus. Decio alcanzó el imperio gracias al apoyo de la clase senatorial, que nunca vio con buenos ojos el origen

17 Nació en Micowitz (Baja Panonia, actual Hungría) en el seno de una familia senatorial en época severiana, hacia el 201, y falleció en el 251 a los 50 años (Syl. Pol. 40), aunque en algunas estatuas (Floca, 1963: 353-358) y monedas aparece como una persona de edad avanzada. Casó con Herennia Etruscilla, también del ordo senatorial. En el 249, Filipo el Árabe encargó a Decio la pacificación de la frontera con el Danubio (Zos I: 21-2) en su calidad de consul suffectus. Junto a esos desórdenes se produjo la rebelión en Panonia y Moesia de Marino Pacatiano. Filipo tomó la decisión de enviar a Decio nos solo por su prestigio senatorial, sino también por su conocimiento de la región. Había nacido en Sirmium en Panonia Inferior y conservaba lazos familiares y de amigos en la zona. Tras su llegada Marino Pacatiano fue asesinado y sus tropas aclamaron a Decio como emperador. Filipo se enfrentó con sus tropas en el 249 en algún lugar cerca de Verona y fue derrotado y muerto. Todo ello dejó el camino libre a Decio. Su principado terminó en el 251 bruscamente con su muerte en Abricio (Tracia) en el transcurso de la batalla contra el godo Cniva en la que también pereció su hijo Herenio Etrusco. Fue sucedido por Cayo Vibio Treboniano Galo. oscuro de Filipo el Árabe, y no descartó que hubiese participado en la muerte de Gordiano III ( $H A$. Gordian 29-30; Zos. 1:18). Precisamente debe verse en ese intento de restauración de la política tradicional el verdadero sentido de la llegada al poder de Decio, un miembro del ordo senatorial. Uno de los primeros actos del Senado fue otorgar al nuevo emperador el título o sobrenombre de Traianus que era considerado el mejor emperador después de $\mathrm{Au}-$ gusto. La fecha del acuerdo del senado no se conoce, pero debió ser muy temprana, dado que existen monedas con este título desde el 250.

Los motivos debieron ser dobles. En primer lugar, el deseo de restaurar el poder senatorial otorgando al nuevo princeps el título de un emperador ejemplar. En segundo lugar, las similitudes entre Decio y Trajano. El hecho de que Trajano hubiese comandado legiones en la Alta Alemania y establecido estrechos vínculos entre la Panonia y Moesia en el momento de su acceso al trono, al igual que Decio, invitaba a la comparación. El título había sido claramente elegido, Trajano había sido un general con éxitos en su región y había alcanzado una enorme fama como gobernante (Nathan, 2002, 2-3). El propio Decio nada más llegar a Roma en el 249, había puesto en marcha la reconstrucción de las zonas afectadas por el fuego y restauró el Coliseo (Verdugo, 2015,16). Asimismo, impulsó la construcción de unas termas en el Aventino y un pórtico. Toda esta actividad edilicia constituía una llamada a restituir la gloria del pasado y un deseo de emular a emperadores constructores como el propio Trajano. Otra semejanza de Decio con el emperador bético es la exaltación de la virtud de la castidad y la modestia -pudicitia- de su mujer Herennia Etruscilla a la que nombró Augusta en el 249, en clara imitación de los honores de Trajano a Plotina. Conocemos una moneda de plata acuñada en Roma en el 250 (figura 9) en cuyo anverso se representa busto de Herennia hacia la derecha con diadema y se lee: HER ETRVSCILLA AVG. Y en su reverso la Puditicia, con el gesto de taparse la cara con el velo y un cetro en su mano izquierda, y se lee: PVDITICIA AVG. También merece ser destacado el homenaje que rindió Decio a emperadores anteriores o restituidos, con motivo del milenario de Roma, y que se conocen con el nombre de "antoninianos" y que fueron las monedas más comunes durante el siglo III. Son monedas de plata rebajada en cuyos anversos aparecen los emperadores con la corona radiada típica de los llamados "antoninos". 
En su reverso, leyenda con DIVO CONSECRA$T I O$ con el efecto de rememorar, pira funeraria o águila. Con esta iniciativa se pretendía recuperar una tradición desde Augusto que sirviera de base ideológica para la estabilidad política y social con el recuerdo de estos emperadores. Las más abundantes son las de Trajano (figura 10) y Antonino Pío. Siglo y medio separa al primer Trajano del segundo; una recuperación de un sobrenombre, dirigida a alcanzar la prosperidad de la época del emperador que había llevado a Roma a su máxima extensión.

\section{Los spolia trajaneos en el Arco de Constati-} no.-

El prestigio de Trajano se manifiesta en la reutilización como spolia de restos figurativos con su imagen en obras tardías. El ejemplo significativo de este uso será el Arco de Constantino que no es un simple monumento honorífico sobre la derrota de Majencio en el 312 y la llegada al trono de Constantino, sino un testimonio de la reutilización de elementos procedentes de edificios más antiguos que le imprimen auctoritas. Ello fue considerado durante mucho tiempo como un aspecto decadente o como un fenómeno específico de finales de la Antigüedad y del Medioevo; hoy, por el contrario, los spolia deben entenderse como un proceso de renovación funcional presente a lo largo de la historia con características propias según qué épocas (Melucco, 2000, 113).

La elección de las piezas no es casual. El programa iconográfico se basa en la identificación de Constantino con el prestigio Ulpio-Aelio: Trajano, Adriano y Marco Aurelio. Esta es la intencionalidad del monumento, y la imagen que se quiere transmitir. Por tanto, los elementos figurativos son seleccionados para enfatizar dicha relación con la dinastía, trasladando así la fama de aquellos a la del emperador Constantino.

Ya Frothingham (1915), se atrevió a considerar que se trataba de la reutilización de un arco de la época de Domiciano y que Melucco $(2000,114)$ considera que se trata de un arco de Adriano, argumentando a favor de esta hipótesis los estudios que han podido realizarse en la restauración llevada a cabo en los últimos años, que han puesto de relieve una estratigrafía del siglo II para la base de la construcción, y también el hecho de que los tondos adrianeos que habían sido considerados tradicionalmente como piezas de spolia, están colocadas en su primitivo lugar y pertenecen por tanto a la fase de
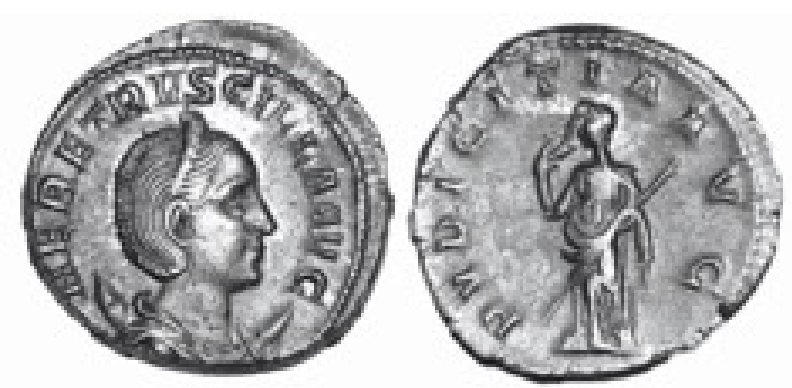

Fig. 9. Denario de Herennia Estruscilla (C) dominio público.

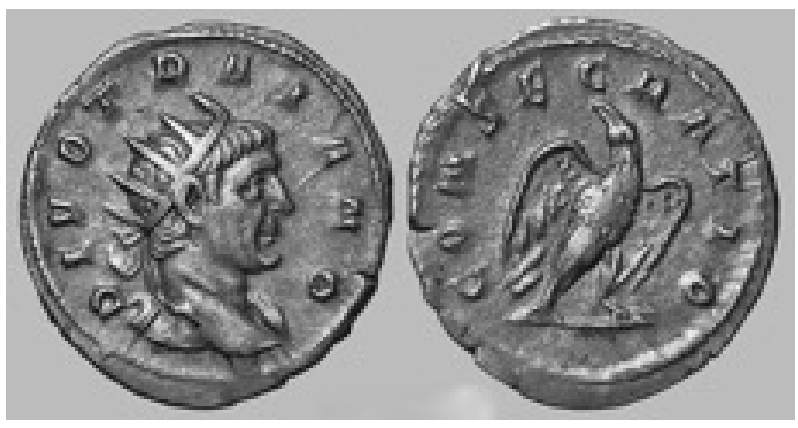

Fig. 10. Antonino de plata acuñado en Mediolanum emisión póstuma de Marco Ulpio Trajano. Anverso: Cabeza con corona radiada del difunto emperador, mirando hacia la derecha. Reverso: Águila estante hacia la derecha con las alas entreabiertas ( $)$ dominio público.

construcción del arco. Así mismo añade, que como ha puesto de manifiesto Conforto (2000, 109-111), se distinguen dos programas constructivos, uno formado por una obra de bloques cuadrados de mármol que se remata con la cornisa principal que está decorada con medallones y otra que descansa sobre dicha cornisa y que corresponde a un ático construido en época constantiniana en opus latericio revestido de mármol. Esto, en su opinión, es una particularidad del Arco de Constantino, toda vez que los áticos de los arcos de Septimio Severo y de Tito en Roma o de Trajano en Benevento son coherentes con la base del arco, y están construidos en opus quadratum con uso de mármol o travertino en los romanos y con piedra local en el de Benevento. Finalmente añade que en el tetrapylum de Malborghetto, erigido por Constantino en el lugar de la batalla con Majencio, toda la fábrica presenta una gran coherencia, y tanto el ático como la parte inferior están realizados en opus caementicium, revestido de lastras de már- 
mol (Melucco, 2000, 115). El programa figurativo del arco se haya organizado en varios episodios, que enfatizan el discurso a transmitir: la fama del Emperador Constantino que se enlaza con la de los emperadores de la dinastía Ulpia-Aelia. En el programa de los tondos originales adrianeos, que envuelve al arco, se aprecian las imágenes del Sol y de la Luna sobre una carroza y una serie de imágenes con escenas de sacrificio y otras dos de cacería, una de ellas manipulada en época constantiniana para introducir un león, que acentúa el carácter hercúleo del emperador, unido a la pietas, representada por la serie de los sacrificios. Junto a este ciclo destaca el friso histórico, qué a modo de narración continuada, no se realiza con lastras esculpidas y luego insertadas sino labradas en el primitivo arco. Son de factura constantiniana y en ella se aprecian la largitio y la adlocutio que tienen lugar en el Foro de Roma. En él se representa el cortejo de entrada del emperador en Roma -adventus-, con un discurso del emperador-oratio- y una distribución de donaciones -largitio (Bianchi Bandinelli, 1971).

Los relieves trajaneos conmemorativos de la empresa militar en la Dacia, situados en la hornacina central del arco, representan el Adventus con el emperador coronado por la Victoria (figura 11) y en frente, la escena del emperador a caballo poniendo en fuga a los bárbaros. Según parece fueron manipulados, pues la cabeza de Trajano fue cambiada por la de Constantino.

También pertenecientes al periodo trajaneo son las esculturas de los bárbaros cautivos situados sobre las columnas, y que proceden del Foro de Trajano (figura 12).

Por otro lado, los ocho relieves (figura 12) del ático parecen provenir de un arco de Marco Aurelio, tal vez un tetrapylum erigido después del 180 (García Bellido, 1972, 486-487); en ellas se narran diversas escenas del emperador antonino, una de ellas representa a Marco Aurelio con su general Claudio Pompeiano sobre una tribuna -suggestus-, rodeado de insignias y soldados. Otra presenta a ambos personajes como tribunal que juzga a los bárbaros prisioneros. En las demás se aprecia una adlocutio del emperador, nuevamente acompañado de su general y una escena de sacrificio de ambos protagonistas. La posición de relieve que ocupan hizo pensar a Torelli $(1993,99)$ que el primitivo arco era de Marco Aurelio, y que Constantino lo habría reutilizado en función de su ubicación junto al Pomerium y la Meta Sudans y la vía triunfal,

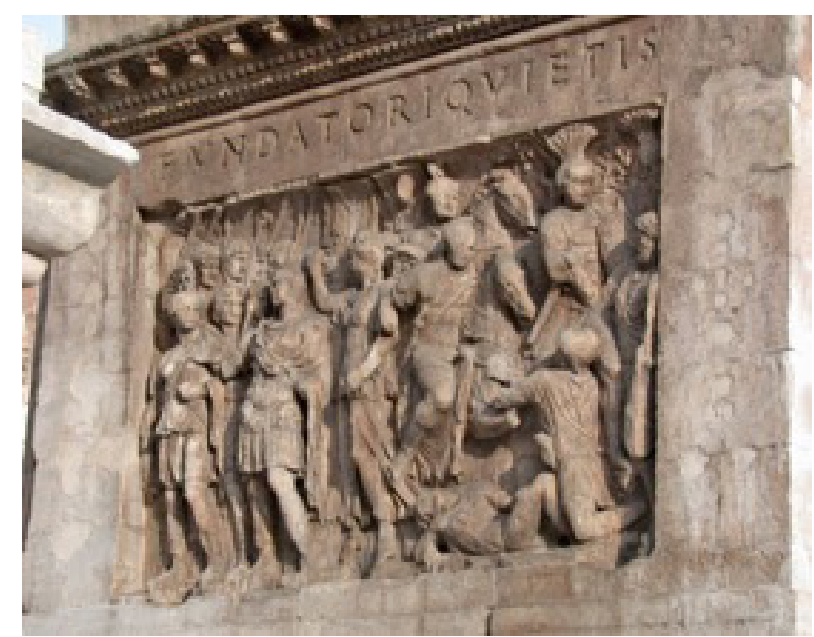

Fig. 11. Escena del adventus representando a Constantino sobre un relieve de Trajano manipulado. Hornacina central del Arco de Constantino $\odot$ dominio público.

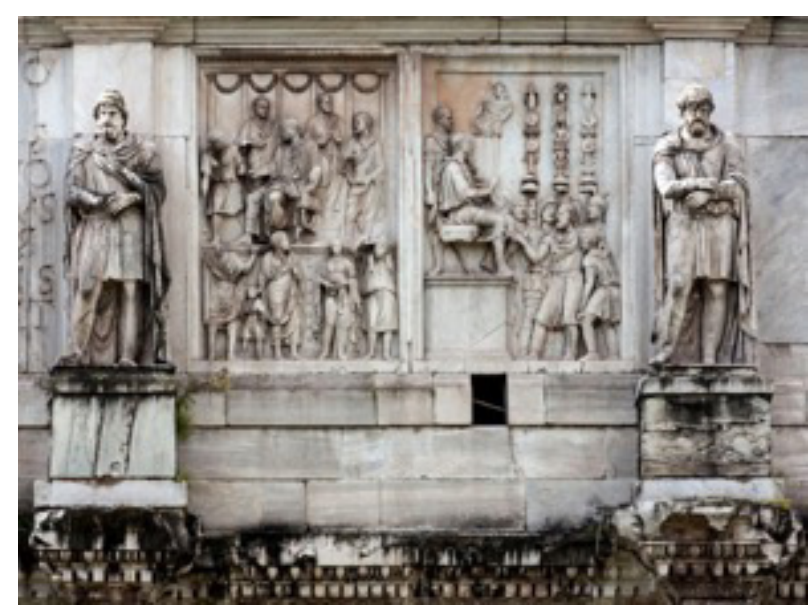

Fig. 12. Arco de Constantino, relieves manipulados procedentes de un arco de Marco Aurelio y dacios cautivos procedentes de la basílica Ulpia (C) dominio público.

esta tesis aunque refutada por Melucco, por la razones ya expuestas, si pone su acento en una realidad incuestionable: Constantino reutiliza este arco en función de su ubicación, que no es arbitraria ni casual, y destinada a enfatizar retóricamente la percepción de la continuidad del poder, haciéndolo visible en un espacio estratégico, que estaba ocupado por un Arco de Adriano. Además, lo que enfatiza es el consensus, que se convierte en la clave para la lectura del mensaje del arco expresado a través de un cuidado discurso figurativo en un lugar lleno de significado público (Melucco, 2000, 123). 
Trajano como ejemplo para Juliano.

La fama de Trajano como conquistador, primero de la Dacia ${ }^{18}$, cuya gesta dejó esculpida en su columna y más tarde con sus campañas orientales, emulando a Alejandro trascendió en el tiempo y así como un gran conquistador nos lo presenta el emperador Juliano (Sym.8, 160-161) en su Banquete o Cronía: Inmediatamente penetró Trajano, llevando sobre sus hombros los trofeos, el de los getas y el de los partos al que coloca tras César y Octavio como uno de los más importantes hombres de guerra (Sym. 17, 167). Esta imagen se ve reforzada en el reinado de Teodosio y de Arcadio como veremos más adelante.

Además, Juliano tras su ascenso al trono imperial (362), intenta restablecer las viejas virtudes republicanas y rechaza el título de Dominus, que consideraba bárbaro, eligiendo como modelos a los emperadores Ulpio-Aelios: Trajano y Marco Aurelio, mis antepasados, que han sido emperadores dignos de la máxima admiración a los que pretendo imitar y cuyas decisiones también en otros temas tengo yo la intención de seguir ${ }^{19}$. Trajano es un conquistador que sigue la estela de Alejandro (González Fernández, 2000, 203-226 y Mangas, 2004, 141-172) y ello es usado por Juliano quien pretende emular su gesta. La guerra de Trajano contra los partos (Angeli, 2000, 25-54; González Fernández, 2000, 203-226) y el oriente (113-117) fue acompañada de éxitos, sometiendo sin lucha a reyes de las distintas regiones, como a Parthamasiris, quien entregó a Trajano la diadema de su reino, acordando Trajano la incorporación de Armenia al Imperio. Después de ello el senado le concedió el título de Optimus ${ }^{20}$ y probablemente el de Imperator VII(Dio LXVIII, 18,3, 23,1.). Tras la anexión de Armenia, Trajano se dirigió a Mesopotamia, estableciendo en Edessa su cuartel general. Después de una campaña militar victoriosa con la ocupación de Nisibis, Singara y Batnae, Trajano se aseguró el

18 Sobre la conquista de la Dacia, véase Bennett, 2001, 85-103; Lago, 2008, La Regina, 1997,117-135 y Schmitz, 2005.

19 Texto del papiro publicado por Grenfell, Hunt y Hogarth, Fayun towns and their Papyri, pp. 116 y ss, XX, tab. VI y The Oxyrhynchus Papyri, XIV,1920, p. 29, que lo atribuyeron a Alejandro Severo. Hoy se considera que es atribuible a Juliano (Leyes, 72b, 288-289, nota 10, ed. García Blanco, C. y Jiménez Gazapo. P., 1982).

20 Entre el 10 de agosto y el 1 de septiembre de 114 (González Fernández, 2000, 207). El de Imperator VII antes del 10 de diciembre de 114 (González Fernández, 2000, 208). control de la Mesopotamia del Norte, como se ve reflejado en monedas con la leyenda: ARMENIA ET MESOPOTAMIA IN POTESTATEM P.R. REDACTAE (Gonzalez Fernández, 2000, 210 y Gabriella/Bertinelli, 2000, 25-54). Después regresa a Antioquia, donde le sorprende el terremoto, ya aludido, en enero de 115. En la primavera de dicho año, Trajano se dirige al Tigris, llevando barcos sobre carromatos con los que construye un puente de barcas sobre el río. Se apodera de la totalidad del territorio. Luego regresó al Eufrates a Doura-Europhos, allí concentró todas sus tropas, volvió a trasladar sus barcos desde el Eufrates al Tigris e invade la Mesopotamia meridional, apoderándose de Babilonia, Seleucia y Ctesifonte (Soria Molina, 2015, 313-332). Esta conquista de Armenia y Mesopotamia en tan corto plazo generó en Roma un gran entusiasmo recibiendo por ello el título de Parthicus por el Senado el 20 de febrero de 116. A su vuelta en el 117 le sobrevino la muerte en Selinunte.

Juliano se inspiró en las victorias de Trajano sobre los partos, para su campaña contra los persas que inició desde Antioquía en el 362, y que le costó la vida en la batalla contra el ejército de Sapor en el 363. Deseoso de obtener los trofeos que Trajano cosechó y su ambición de gloría trajo consigo una campaña desastrosa para Roma.

LAS COLUMNAS DE TEODOSIO Y ARCADIO DE CONSTANTINOPLA: LA ASUNCIÓN DEL PRESTIGIO ULPIO-AELIO.

Estas columnas son consecuencia del programa oficial de Constantino tendente a hacer de Constantinopla una segunda Roma (Sócrates I, 16; P.G. LXVII, 116 C.). Ahora bien, esta nueva Roma, debía ser en todo, heredera y emula de la otra (Becatti, 1960, 83), el decreto que confería derechos y privilegios a la Nova Roma se colocó sobre el viejo Strategion junto a la estatua ecuestre de Constantino. Todo se hace copiando a Roma, XIV regiones, un Septimontium con Teodosio II, un Capitolium, un Milion más fastuoso que el Milliarium aureum, Foros, Vía Sacra, una Curia senatorial, y junto a la Tyché de Constantinopla se colocó a la diosa Roma, Constantino colocó el Palladium romano sobre su Columna en el Foro y se proclamó Conservator et Restitutor Republicae.

En este capítulo de imitaciones, sorprende que la introducción de las columnas "coclidias" historiadas se hayan limitado a dos y que haya sido Teodosio y su sucesor Arcadio los que las erigieran (Becatti, 1960, 83). El motivo parece ser patriótico. 


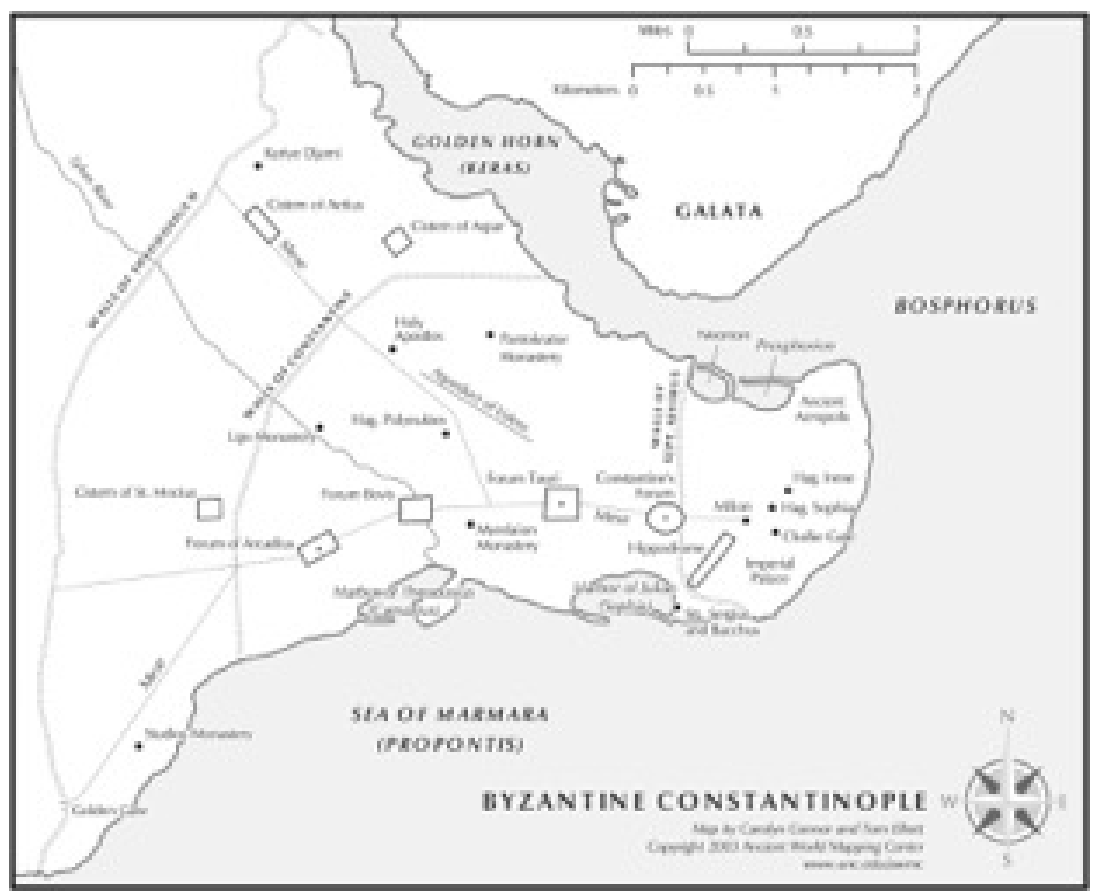

Fig. 13 Plano de Constantinopla, con la ubicación del Forum Tauri, donde se hallaba la columna de Teodosio y el Forum de Arcadio, donde se ubicaba la de este emperador $(\subset$ Ancient World Mapping Center 2003.

Teodosio remontaba su descendencia hasta Trajano, hispano como él. El galo Latinio Pacato (Pan. IV, 2-5), en su panegírico a Teodosio en el verano del 389 en Roma, con ocasión de su victoria sobre Máximo, recuerda a Hispania como patria de Teodosio: Haec Traianum illum; haec deinceps Hadrianum misit impero, huic te debet imperium. Este origen hispano y descendencia de Trajano será exaltada por Claudiano (de IV cons. Honor. VIII, 18-20): Ulpia progenies, Ibera domus. De estas referencias parece colegirse que primero Teodosio y después Arcadio, imitan así no sólo la grandeza de Roma, erigiendo estas columnas, sino que también se entroncan de este modo con Trajano, prestigiando su poder con la emulación de su antepasado. De la misma manera, que Constantino engrandeció el primitivo Foro de Septimio Severo, inspirándose en Oriente, Teodosio continuará este programa erigiendo uno nuevo el Forum Tauri (figura 13) a lo largo de la Mese, pero a diferencia de Constantino se inspirará en Occidente, y más precisamente en el Foro de Trajano. Dos son las ideas que toma de dicho foro. La primera la de erigir la columna y la segunda una grandiosa estatua ecuestre, en bronce dorado, de Teodosio que, sin embargo, a diferencia de la similar de Trajano -situada en atrio medio- ${ }^{21}$, no estaba en el centro de la plaza. Esta estatua de Teodosio se alzaba sobre un zócalo decorado, que según la descripción de Constantino Rodio (Downey, 1955 21-221) y de Cedreno (I, 566) representaba la victoria sobre Máximo y sobre los Escitas en Tracia. El caballo iba al galope ${ }^{22}$, bramando, con el cuello erguido, mordiendo el freno, orgulloso de llevar a la grupa a su victorioso señor, quién indicaba con su mano derecha a la ciudad la dirección de la columna, en la que se mostraba su victoria sobre los bárbaros, representada en el friso espiriforme. En la Anthologia Palatina (XVI, 65) se ha conservado un epigrama que seguramente estaba inciso en el basamento de la escultura: "Tu surges del Oriente como otro Sol radiante sobre los mortales, iOh Teo-

21 Amiano Marcelino, XVI, 10, 15.

22 Conocemos unos medios centenionales acuñados en Cízico y en Alejandría que representan a Teodosio a caballo, caminando hacia la derecha, con su mano derecha alzada, pero el caballo aquí representado va al paso y no al galope. Estas monedas presentan las leyendas de D.N. THEODOSIVS P.F AVG, en su anverso y GLORIA ROMANORVM en su anverso. Fueron acuñadas entre el 392-395. No podemos asegurar que la representación de estas monedas sea la de la estatua del Foro. 
dosio!, en el centro de la bóveda celeste, itú benéfico!, teniendo a tus pies el Océano junto a la Tierra infinita, armado y todo resplandeciente, y dominando fácilmente, itú magnánimo!, el espléndido caballo galopante". La utilización de las imágenes del Océano y de la Tierra, seguramente dos esculturas, representadas en el momento de tocar con la mano los pies del emperador ${ }^{23}$, añaden un sentido cósmico a la maiestas de Teodosio, que aparece así como señor del Universo, que se materializa en el globo que portaba en su mano izquierda y que sabemos se desprendió con ocasión de un terremoto acaecido en el 480, que derribó también la estatua que coronaba la Columna ${ }^{24}$. La estatua ecuestre se encontraba en la encrucijada de la vía principal y la plaza, que era visita obligada de los embajadores extranjeros que llegaban a la ciudad recorriendo la Mese. Este uso se remontaba a una antigua tradición constantiniana, puesto que, en este lugar, llamado el Alonitzion, se habían construido en dicha época una serie de modestos palacios para acoger a los personajes y embajadas que llegaban de Roma. Probablemente la construcción del foro por Teodosio, destruiría estos pabellones, pero si se mantuvo la tradición de recorrer este camino por los visitantes (Becatti, 1960, 96).

Más al interior del foro debía alzarse la Columna y es probable que ocupara el centro de un espacio definido por dos pórticos con dos arcos sobre los que se elevarían en altas basas cuadrangulares las estatuas de los dos hijos de Teodosio.

La arquitectura de la Columna imitaba en todo a la de Trajano en Roma, así el toro de la base, estaba decorado con los mismos tipos de guirnaldas y el equino formaba idéntico motivo de óvalos. Con la construcción de su columna Teodosio, buscaría seguramente repetir el efecto que la de Trajano producía en el visitante, como la que nos recuerda Amiano Marcelino (XVI, 10.15) con ocasión de la visita a Roma de Constancio en el 356: singularum sub omni caelo structuram, ut opinamur, etiam numinum adsensione mirabilem. El mismo Teodosio tuvo ocasión cuando visitó Roma, tras su victoria sobre Máximo en el 389, de contemplar el Foro de Trajano, a quien consideraba su

23 Según Becatti $(1960,90)$ dicha representación sería parecida a la de la Tierra en el Marfil Barberini o en la descripción de Niceta Choniate (De signis, 10) de una estatua ecuestre sobre una columna del Hipódromo.

24 Theofanes (a.n. 5970, Bonn, pp. 194-195); Cedreno (I, 168, 20, Bonn) y León Gramatico (p. 118, 5, Bonn). antepasado (Canto, 2006), y fue en ese momento cuando pudo concebir la construcción de otra análoga en el importante programa constructivo que estaba llevando a cabo en Constantinopla y que es referido por $\mathrm{Pacato}^{25}$ (XLIV) en su Panegírico, con clara referencia a que se inmortalicen en piedra las hazañas de Teodosio: "Y vosotros también artistas de la plástica, a quienes después de los poetas, ha tocado en suerte ilustrar los acontecimientos, dejad a un lado esos temas ya divulgados de los viejos mitos, los trabajos de Hércules, los triunfos indios de Baco, la guerra de los monstruos de colas de serpiente. Estos, estos son más bien los hechos que deben reproducir vuestras hábiles manos: que ellos decoren nuestras plazas, que sean representados en marfil y en mármol, que revivan en la pintura, que sean trasladados al bronce, que aumente el valor de las piedras preciosas".

La columna representaba en sus relieves escenas bélicas del emperador, y para intentar saber cuáles reflejaba debemos nuevamente recurrir al Panegírico de Pacato (X). Efectivamente éste nos dice: "Apenas habías tu entrado en tu morada en Hispania cuando te hallabas ya al abrigo de la tienda de campaña, entre los sármatas ${ }^{26}$; apenas habías colgado, al término de una campaña, tus armas en la pared, cuando las volvías ya a tomar y acosabas, apremiadamente al enemigo; acabas de estar viendo al Ebro en tu país y acampas ya a orillas del Hister”. Estas campañas contra los bárbaros sármatas $\mathrm{y}$ tracios fueron, con toda probabilidad los motivos decorativos de la columna. Y de forma especial la campaña del 386 contra los ostrogodos guiados por Odoteo, que habían irrumpido durante el verano a lo largo del bajo Danubio, y que fue dirigida por el magister militum per Thracias, Promoto, que fue hecho cónsul el 389, y que destruyó los navíos fluviales de los bárbaros en el Danubio, haciendo grandes estragos y conduciendo a la victoria al ejercito romano. Teodosio, junto con su hijo Arcadio, estableció la paz y el 12 de octubre entró cum victoria et triumpho en Constantinopla. De este

25 Latinio Pacato Drepanio fue recompensado con el proconsulado de África en el 390, y sabemos que en el 393 se encuentra en Constantinopla como comes rerum privatorum en la corte de Teodosio y sus ideas e ideales, en el estrecho círculo de asesores del emperador, bien pudo influir en aquella corriente artística, de recoger hechos históricos, de la que nace la propia Columna de Teodosio.

26 Campaña contra los sármatas al sur del Danubio y vic toria de Tracia. 


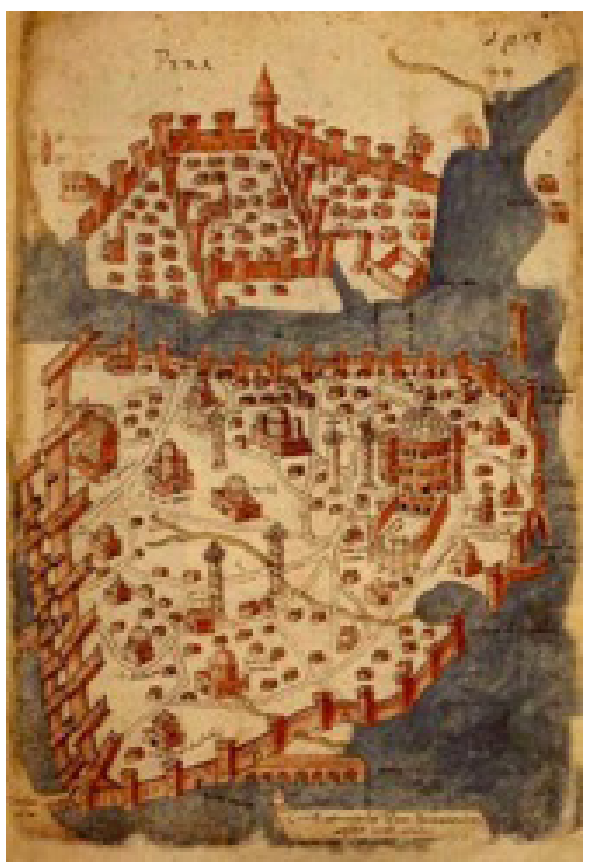

Fig. 14. Vista de Constantinopla con las columnas de Teodosio y Arcadio. Cristoforo Buondelmonti 1422, Liber Insularum Archipielagi, Cott.Vesp. A XII, f 36v British Museum () Trustees of the British Museum.

modo, el relieve de la columna recogería esta victoriosa campaña y también la que se realizó contra el usurpador Máximo. Si el friso seguía un discurso cronológico, el triunfo sobre los bárbaros se desarrollaría en la parte baja del friso, mientras que la campaña contra Máximo ocuparía la parte menos visible, en todo lo alto. En cuanto al basamento de la gran estatua ecuestre en él se desarrollaría una alegoría, que mostrara al Universo la res gestae del emperador soberano del mundo grecorromano.

La fecha de los trabajos de la columna debe situarse entre el 386 y el 394, fecha ésta en la que se colocaría la escultura que la remataba. Es decir, siete años, tiempo muy razonable, si tenemos en cuenta que la de Trajano se terminó en seis. Es muy probable que cuando Teodosio inauguró el Forum Tauri en el 393 la columna estuviese terminada y al año siguiente colocó su escultura en ella como colofón de su programa (Becatti, 1960, 104).

La columna tras el terremoto del 480 quedó privada de la escultura de Teodosio que cayó al suelo y en el 506 Anastasio hizo fundir estos trozos juntos a los de otras estatuas de la época de Constantino para fundir una suya que colocó sobre la Columna (Theoph. A.m. 5998, Bonn, 229), y que segura- mente fue destruida en el 512 junto a las imágenes de este emperador.

En el siglo XV nos hablan de la columna Manuel Chrysoloras $^{27}$ y Ciriaco de Ancona ${ }^{28}$ y Cristoforo Buondelmonti (Manners, 1997, 72-102) en su Isolaro dell'Arcipelago dedicado al Cardenal Orsini en 1420 (figura 14). En varios manuscritos aparecen unas vistas de las columnas en unas panorámicas de Constantinopla.

La columna fue destruida, según parece, en la época del sultán Bayazid II a comienzos del quinientos, para la construcción de un baño, en cuyos cimientos es probable que aún se hallen fragmentos de la columna. Esta teoría parece ser confirmada por la existencia de algunos fragmentos del fuste historiado en el propio Baño del Sultán y por el hallazgo en dicho lugar de otros fragmentos, que se encuentran hoy en el Museo de Estambul (figura 15). La columna de Teodosio no aparece en las vistas de la ciudad de Mattia Lorichs de 1559 donde si aparece, sin embargo, la de Arcadio, que fue destruida en 1715 (Becatti, 1960, 99).

En cuanto a la Columna de Arcadio (Geffroy, 1895, 99-130 y Taddei, 2009, 37-103) forma parte del programa constructivo que se concretó en torno a un Foro, que aquél ordenó construir en la región de Xerolophos, en un lugar llamado Theama que fue sede de un antiguo culto a Apolo. Este lugar, estaba situado muy al oeste del foro de su padre, y alejado lo suficiente del mismo para no alterar las áreas monumentales teodosianas. La intención de Arcadio fue continuar la tradición familiar y dinástica, repitiendo los motivos arquitectónicos del Forum Tauri, como atestiguan Constantino Rodio (Const. Rhod. Ekphrasis, v. 243) y Cedreno (Cedren. 567) que lo consideran idéntico al Tauri, como similar era la columna del hijo a la del padre según el testimonio de los Patria (Preger. 176, 16 ss.). Constantino Rodio (Const. Rhod. Ekphrasis, v. 241-254) hace uso de una metáfora militar al comparar las dos columnas y así nos dice que la de Teodosio "controla" el centro de la ciudad, mientras que la de Arcadio mira hacia las "puertas doradas", una guardando el centro y la otra la periferia (Taddei, 2009, 47).

El Foro de Arcadio debió tener una planta rectangular, pero no sabemos si tenía también una es-

27 Epist. ad Ioan. Imp. 1792.
28 G. Colucci, Delle antichitá picene,XV, Fermo 


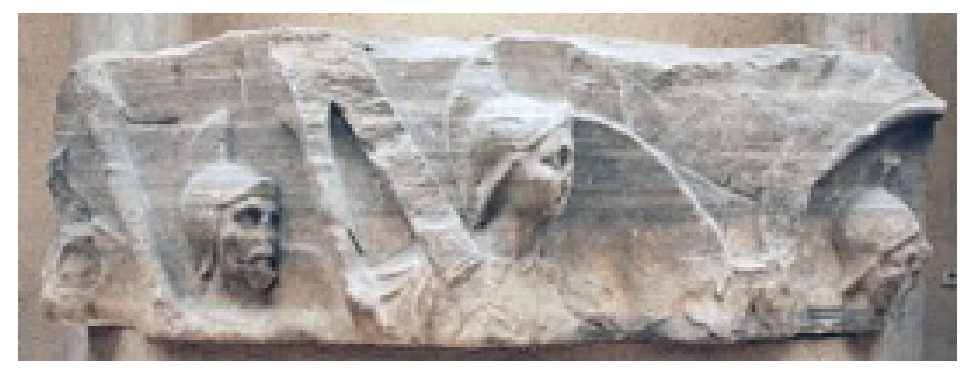

Fig. 15. Fragmento de la columna de Teodosio @ Museo de Estambul.

tatua ecuestre como la de su padre y si la columna estaba situada en el centro de la plaza. Los primeros trabajos de la columna se realizaron entre el 402 y 403 según testimonia Teófanes (Theophan. a. m. $5895)$. Taddei $(2009,50)$ considera que debieron iniciarse los trabajos en el 403 junto al resto del foro. Becatti $(1960,153)$ adelanta la fecha al 401-402 pues en su opinión la erección de la columna debe situarse después de la victoria sobre Gainas que fue derrotado el 23 de diciembre del 400 y cuya cabeza desfiló por las calles de Constantinopla inserta en una lanza el 3 de enero del 401. Sin embargo, parece probado por los testimonios del comes Marcellino (Chronicon , 75.2, Croke, 2001, 114) y por el Chronicon Paschale (Dindorf, 1832, 579,15) que la columna fue acabada e inaugurada con la colocación en su cima de la estatua de Arcadio en el 421 por su hijo Teodosio II (Taddei, 2009,51).

En agosto del 542 un terremoto hizo caer el brazo derecho de la estatua (Theophan. a. m. 6034) y el 24 de junio del 550 un rayo dañó la estatua y la parte superior de la columna (Theophan. a. m. 6041) y el 26 de octubre del 740, otro terremoto terminó por hacer caer la estatua. En cuanto a lo que respecta a los motivos decorativos los Patria (Preger. 176, 16 ss.) nos dicen que los mismos representaban los últimos acontecimientos históricos de la ciudad, sin que tengamos detalles de la decoración, salvo generalidades como las de Manuel Chrysoloras (Epist. ad Joan. Imp. CLVI, 45). Hay que esperar a la descripción que de la columna nos hace Petrus Gyllius (De tpographia Constant. IV, 7), de todos los elementos de su estructura, midiendo las partes y analizando las formas arquitectónicas. Del fuste nos indica que en él hay esculpidas escenas de batallas. En los dibujos de Freshfield $(1574 \text {, ed. } 1922)^{29}$ la columna aparece dañada (figu-

29 Los dibujos de la columna recogidos por Freshfield ra16), habiendo sido necesaria la colocación de aros de hierro para reforzarla, como nos informa $\mathrm{H}$. de Beauveau, en 1605 , pues ya estaba muy deteriorada más por los turcos que por el tiempo. Graviers d'Ortières (1686, Vol. II, p.2) da una descripción muy precisa de la columna y que las figuras están muy arruinadas, sin embargo, reconoce en ellas asedios de ciudades y combates marítimos. Las figuras, continúa "están vestidas a la romana” y son excelentes. La escalera interior estaba por algunas partes y la base estaba cerrada por casas turcas colindantes.

En cuanto a la composición de las espirales, es probable en opinión de Becatti $(1960,164)$ que se alargasen progresivamente hacia arriba para corregir ópticamente la reducción debida a la altura, como ocurre en las antoninas de Roma. También, por lo que conocemos, en las columnas de Teodosio y Arcadio, se advierte la evolución del principio ya contemplado en la de Marco Aurelio en Roma, de desarrollar en un lado la escena más importante, subrayando así ese lado como fachada del monumento. En la de Marco Aurelio se desarrolla la escena principal hacia la Vía Flaminia, en la de Teodosio hacia la Mese, mientras la de Arcadio lo haría hacia su lado meridional, desde donde se conectaría el Foro de Arcadio con la arteria principal.

En cuanto a la res gestae que fueron recogidas en el fuste de la columna, ya hemos afirmado, siguiendo a Becatti ${ }^{30}(1960,164-166)$ que con toda

fueron realizados probablemente por Antonio Lambert de Vos, natural de Mechlin o Mechelen (Antwep. Flandes. Bélgica), sabemos que perteneció al gremio de San Lucas de esa ciudad, en 1563 viajó a Constantinopla y allí confeccionó una serie de dibujos sobre vestidos orientales (1574) que se conservan en la biblioteca de Brenen. Los dibujos de la columna se hallan en el Cambridge Trinity College, ms. 0.17.2 (Taddei, 2009, Tav. V).

30 El friso de la columna tendría la siguiente distribu- 

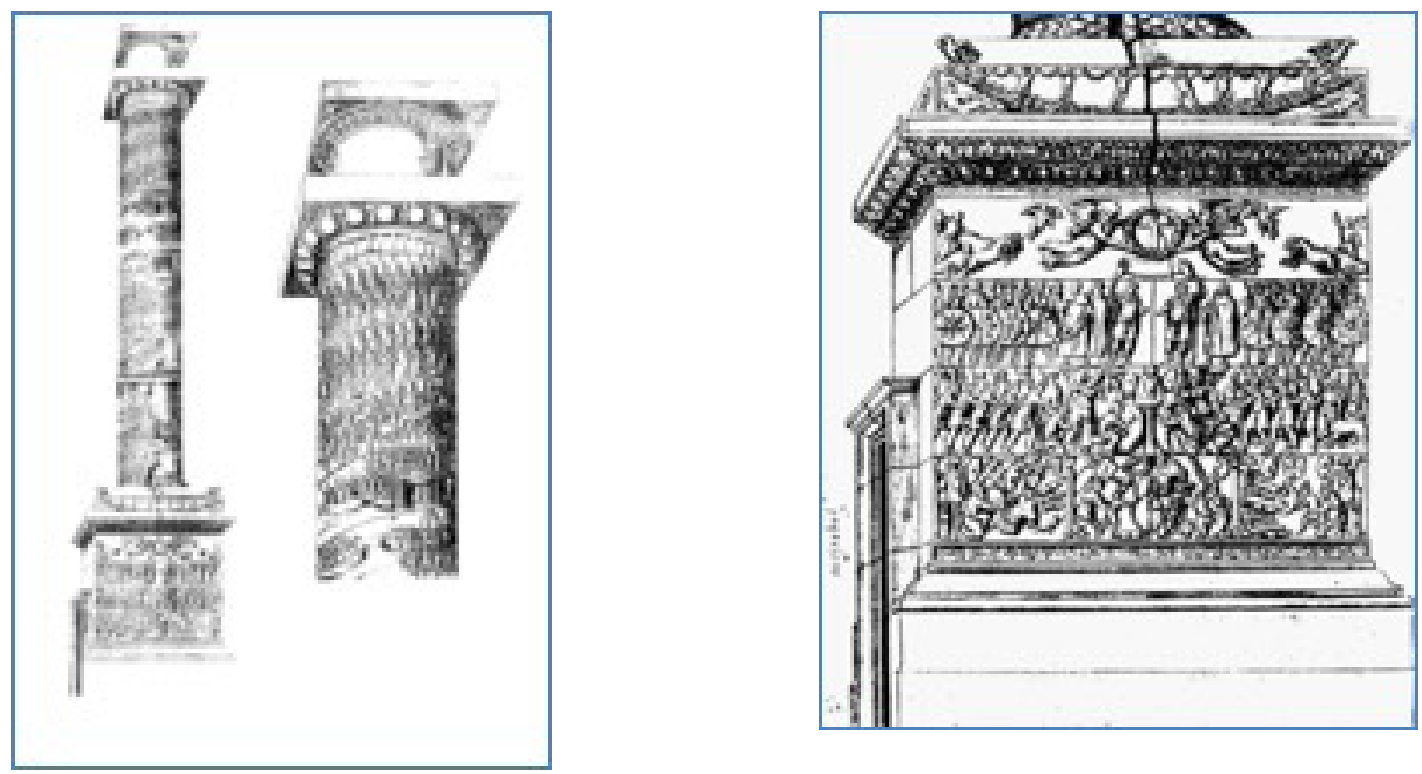

Fig. 16. Antonio Lambert. Izquierda, la columna de Arcadio vista desde el oeste y particular de la parte superior. Derecha, detalle del basamento.

probabilidad se refieren a los acontecimientos relacionados con la sublevación del godo Gainas. Si las columnas de Trajano y Marco Aurelio celebraban empresas guerreras, tanto la de Teodosio como la de Arcadio tenían que responder a idéntico esquema. Las columnas aparecían ante los ojos de sus contemporáneos como un gran volumen marmóreo figurado, como una narración en piedra de unos hechos ciertos. Los hechos que recogen la columna de Arcadio debían representar acontecimientos importantes y por ello recordables por la población. No podía ser una continuación de la narración de los hechos recogidos por su padre en su columna, sobre el triunfo sobre los ostrogodos, pues ya aparecería Arcadio, seguramente, en dicha narración. De ningún modo podía ser reiterativo. Ello no tendría sentido para el público: último destinatario de estos monumentos intencionados. Tampoco podría ser traducido en tema digno de celebrar el ataque de Alarico en el 395 a Constantinopla y que fueron alejados mediante acuerdo por Rufino, posteriormente combatidos por Estilicón venido desde Oriente como libertador del Imperio. Los acontecimientos que se sucedieron, asesinato de Rufino el

ción. En su primera parte Ganias y su familia y su marcha por tierra con la derrota de sus barcos en la escena sucesiva, que se cerraría con el triunfo final de las tropas imperiales con la presencia de los emperadores desde el sexto al décimo y decimotercero giro.
27 de noviembre del 395, y conspiraciones de Eutropio y otros ministros de Arcadio oponiéndose a Estilicón, favoreciendo a Alarico, no eran dignas de ser celebradas en un friso de una columna. Sin embargo, sí parece más plausible que la columna recogiese los acontecimientos que se vivieron con el golpe militar del godo Gainas en el año 400 ocupando por un breve espacio de tiempo la capital. Gainas, que estaba al servicio de Arcadio, había sido mandado a combatir a otro godo de su misma estirpe (Cameron, 1998, 31), Tribigildo, que se dedicaba a devastar el Asia Menor. Se unió a él y ambos marcharon contra Arcadio. La cuestión que se plantea en este suceso, es la toma de conciencia de los romanos orientales, de la necesidad de sacudirse del poder de estos reyes o caudillos germánicos para siempre. Y tal vez sea esa la cuestión del por qué se utiliza esta acción en la columna. Los ciudadanos de Constantinopla lo asociarían a sus anhelos de libertad. No por casualidad se alzaron contra los godos los propios habitantes de la ciudad, que aniquilaron a muchos de los soldados y partidarios de Gainas, quien tuvo que abandonar Constantinopla, y huir con su flota que fue derrotada, curiosamente por otro godo al servicio del imperio: Fravittas, que fue nombrado cónsul en el 401, y que participaría en el triunfo de Constantinopla con Arcadio.

La columna sin trabajos de consolidación ni restauración se convirtió en una amenaza para las 

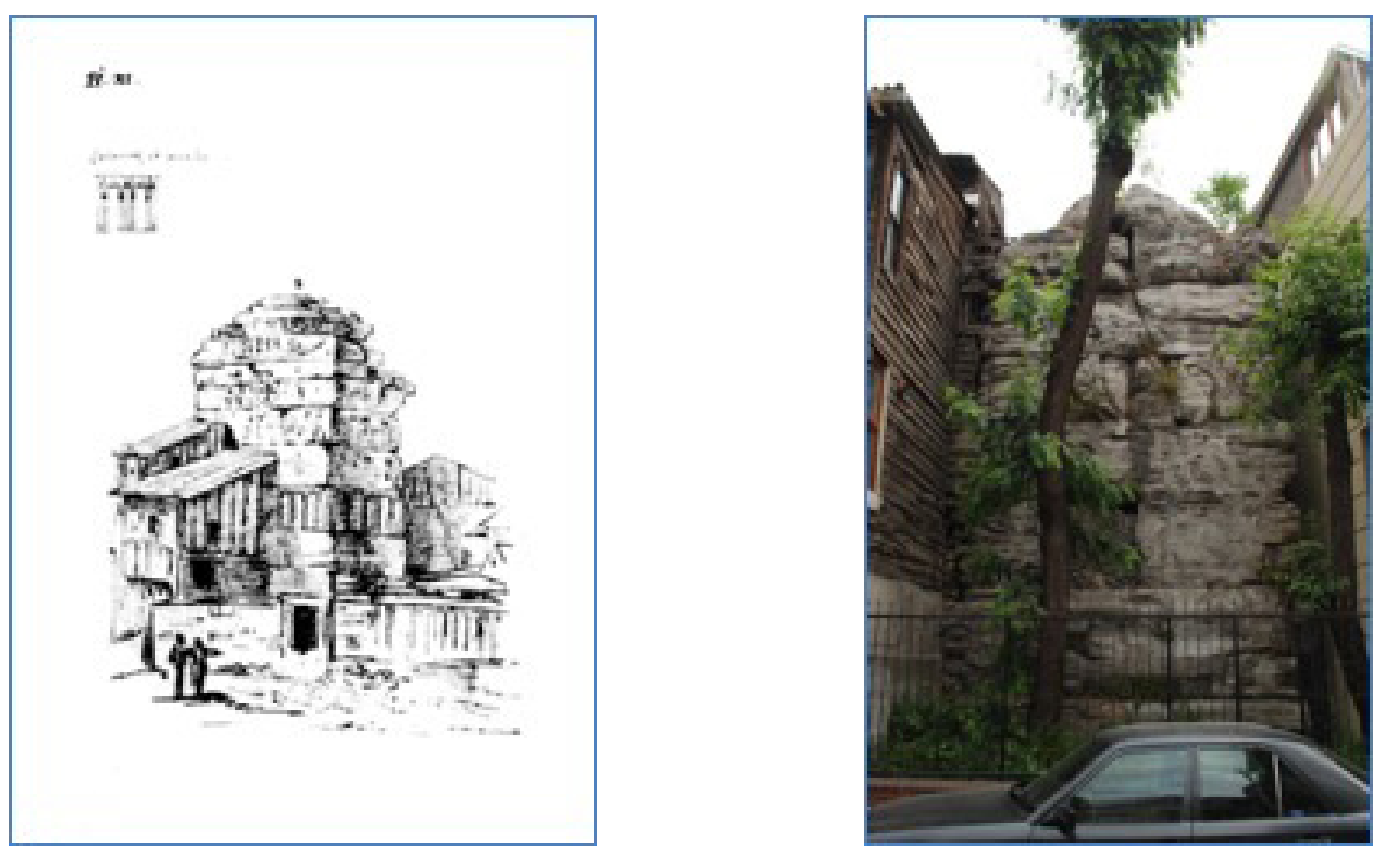

Fig. 17 Izquierda, particular del basamento de la columna de Arcadio rodeada de casas, dibujo de L.F. Cassas (1784), Biblioteca Vaticana, Vat. Lat. 9840, f. 30 v @ B BAV (Taddei, 2009, Tav. VII). Derecha, el basamento en la actualidad (C) dominio público.

viviendas del barrio turco a ella cercanas y por ello en $1715^{31}$ se tomó la decisión de derribarla, dejando solo el basamento que aparece en un dibujo de 1784 de L.F. Cassas publicado por Seroux d'Agincourt ${ }^{32}$ con casas a él adosadas (figura 17). Los turcos lo denominan "Avrat Tasi" o Piedra de las Mujeres, derivado del popular "Avrat Pazari” o Mercado de las Mujeres. Los restos del basamento se hallan en la actualidad constreñidos entre viviendas en la esquina entre Haeki Kadin Sokagi y Cerrahpasa Caddesi. Lo que nos ha quedado es un paralelepípedo formado por bloques de mármol proconnesio con una base de 6 x 6 metros y una altura de 10 metros, que corresponde al pedestal de la columna coronado por un muñón del primer bloque del fuste, cuyo diámetro máximo alcanza casi los 5,40 metros y una altura de 1,490 metros (Taddei, 2009,48).

31 Aubry de la Motraye, Voyages en Europe, Asie et Afrique, L'Aia 1727, p. 266; carta de la señora Wortly Montague, Amsterdam 1763, p. 206.

32 J.B. Seroux D'Agincourt, Historie d l'art, 1823. El dibujo de L.F.Cassas (1756-1827) se encuentra en la Biblioteca Vaticana, Vat. Lat. 9840, f. 30 v. (Taddei (2009), Tav. VII).

\section{Conclusión}

Trajano se convirtió en un ejemplo no solo para su tiempo, sino para los emperadores sucesivos como Teodosio o Juliano, según nos relata la abundante historiografía antigua. Conquistador de la Dacia y victorioso con los partos, igualó en fama al propio Alejandro, siendo declarado Optimus Princeps. Fue un hombre piadoso que extremó su respeto por las minorías como los cristianos de Bitinia-Ponto y creó la institución de los alimenta para la integración de los niños y niñas huérfanos del Imperio. Permitió el testamento militar excepcional libre de formalismos para los soldados y combatió la corrupción. De este modo Trajano y su dinastía la Ulpia-Aelia se convirtieron en modelo de imitación. Varios elementos contribuyeron a ello: su fama que sobre él trasmitió su panegirista Plinio y los historiadores del momento y sucesivos, lo que supuso un deseo de imitación de sus virtudes y la de su dinastía Ulpia-Aelia, en especial por los emperadores hispanos posteriores como Marco Aurelio que erigió su columna en Roma a imitación de la de Trajano y Teodosio el Grande y su hijo Arcadio que erigieron otras dos en Constantinopla.

La historia nos ha dejado la paradoja de que se conserven aún en nuestros días las dos columnas 
historiadas Ulpia-Aelias de Roma, que sirvieron de ejemplo a estas dos de Constantinopla, que fueron destruidas por la falta de interés por el pasado de los turcos, frente al interés patriótico del Senado de Roma que estableció pena de muerte a quien produjera daño a la Columna de Trajano, y la Iglesia que estableció la excomunión para quien dañase a la de Marco Aurelio. Columnas que fueron más tarde restauradas y reinterpretadas por Sixto V (Verdugo, 2017b) y que se mantienen en el lugar en que fueron erigidas.

La fama de Trajano trascendió desde la Antigüedad hasta las postrimerías de la Edad Moderna. Fue reconocido con el título de Paladín de la Justicia, merced a la ideoescena de la "Leyenda de la Viuda”, resucitado por Gregorio Magno por sus virtudes para ser bautizado y volver a morir en paz y residir en el Sexto Cielo del Paraíso donde lo encuentra Dante, en su Divina Comedia. Numerosos tapices, frescos o arcas nupciales recogerán esa fama de su justicia.

Bibliografía

Alföldy, G. (2000), "Trajano padre y la inscripción del Ninfeo de Miletos", Trajano, emperador de Roma (J. González Fernández, Ed.), Roma, 11-24.

Angeli Bertinelli, M.G.,(1998), “Traiano in Oriente: La conquista dell'Armenia, della Mesopotamia e dell'Assiria”, Trajano emperador de Roma (J. González Fernández, J. Ed.), Roma, 25-54.

Arce, J. (1988), Funus Imperatorum. Los funerales de los emperadores romanos, Madrid.

(1998), "Muerte, consecratio y triunfo de Trajano", Trajano emperador de Roma (J. González Fernández, J. Ed.), Roma, 55-69.

(2003), "El emperador Trajano en los textos tardíos" Marco Ulpio Trajano. Emperador de Roma. Documentos y fuentes para el estudio de su reinado (J. C. Saquete y J. González Fernández, J. Coords), Sevilla, 303-330.

Beauveau, H. De (1619) Relation journalière du voyage du Levant, Paris.

Beccati, G. (1960), La colonna coclide istoriata. Problemi storici icografici stilistici, Roma.

Belloni, G. (1973) Le monete di Traiano, Milano.

Bennet, J. (1997), Trajan. Optimus Princeps, Londres.

Bialostosky, S. (1982), "El testamento militar romano y su recepción en el derecho castellano y mexicano", Primer Coloquio italo-mexicano de derecho romano, 313-323.

Bianchi Bandinelli, R. (1971), Roma el fin del arte antiguo. El arte del Imperio romano desde Septimio Severo hasta Teodosio I, Madrid.

Blanco Frejeiro, A. (1988), "Las esculturas del Traianeum", Traianeum de Italica

(P. León Alonso, Ed.), Sevilla, 103-107.

Blázquez. J.M. (2003), "Hispania en el tiempo de Trajano", en El Imperio de Trajano (J.M ${ }^{a}$ Blázquez y J. Alvar, Eds.), Madrid.

Blázquez. J.M. y Alvar, J. (2003) El Imperio de Trajano, Madrid.

Broek, R. van Den (1972), The mith of Phoenix. According to classical and Early Christian tradition, Études preliminaires aux religions orientales dans l'empire Romain. Vol. 24, Brill.

Cameron, A. (1998), El mundo mediterráneo en la Antigüedad tardía. 395-600, Barcelona.

Camozzi, G. (1901) "La consecratio di Traiano", Revista Italiana di Numismatica e scienze affini (RNI), 14, 12-26.

Canto de Gregorio, A.Mํ. (1991), "CIL VI 10229: ¿El testamento de Licinio Sura?”, Chiron, 21, 277-324.

(1998), "Saeculum Aelium, saeculum Hispanum: Promoción y poder de los hispanos en Roma”, Hispania. El Legado de Roma. En el año de Trajano, Madrid-Zaragoza, 209-224. (2003a), "La dinastía Ulpio-Aelia (96-192 d. C.): ni tan 'Buenos', ni tan 'Adoptivos' ni tan 'Antoninos”, Gerión 21.1, 263-305.

(2003 b), Las raíces Béticas de Trajano. Los Traii de la Itálica turdetana, y otras novedades sobre su familia, Sevilla

(2003 c), "Los Traii béticos. Novedades sobre la familia y los orígenes de Trajano”, El Imperio de Trajano (J.M Báázquez y J. Alvar, Eds.), Madrid, 35-27.

(2006), "Sobre el origen bético de Teodosio I el Grande, y su improbable nacimiento en Cauca de Gallecia”, Latomus, 65/2, 388-421.

Colucci, G. (1792): Delle antichitá picene, XV, Fermo.

Conforto, M.L. (2000), "L’Arco dedicato a Costantino: la sovrapposizione di due monumenti", Adriano, architettura e progetto, Milano, 107113.

Cortés Copete, J.M. (2010), “¿Un Traianeum en Itálica?”, Dialéctica histórica y compromiso social, 1 (Fornís Vaquero, Coord.), 583-596.

Croke, B. (2001), Count Marcellinus and His 
Chronicle, Oxford.

Dante, A. (2014), La Divina Comedia, versión poética de Abilio Echevarría, Madrid.

Dindorf, L. (1832), Chronicon Paschale, Corpus Scriptorum Historiae Byzantine, Bonn.

D’Ortières, G. (1686), Description de Constantinople, Bibliothèque Nationale manuscrito 7176.

Downey, G. (1955), "Constantine the Rhodian, his Life and Writings", Late-Classical and medioeval Studies in honor of A.M. Friend, Princeton, 212-221.

Fini, M. (1994), Nerone. Duemila anni di calumnie, Milano.

Floca, O. (1963), "Un monument sculpturel de l'empereur Trajan Decius à Ulpia Trajana Sarmizegetusa”, Latomus, 24, 353-358.

Freshfield, E.H. (1922), "Notes on a Vellum Album containing some original sketches of public buildings and monuments, drawn by a German artist who visited Constantinople in 1574", Archaeologia or Miscellaneous tracts relating to Antiquity, 72, 87-104.

Frothingham A. L. (1915), "Who Built the Arch of Constantine", I-IV, American Journal of Archeology, 19/4, 367-384.

Fustel de Coulanges, N.D. (1983), La ciudad antigua, Barcelona.

Gabriella, M y Bertinelli, A. (2000), "Traiano in oriente: la conquista dell'Armenia della Mesopotami e dell'Assiria", Trajano, emperador de Roma (J. González Fernández, Ed.). Roma, 2554.

García Bellido, A. (1972), Arte Romano, Madrid.

García Blanco, J. (1982), Juliano. Discursos VIXII, Madrid.

Geffroy, A., (1895), "Le colonne d'Arcadius à Constantinopla, d'apres un dessin inédit" , Monuments et mémoires de la Fondation Eugène Piot, II/1, 99-130.

Gil, J. (2000), “Trajano en la Edad Media”, Trajano, emperador de Roma, (J. González Fernández, Ed.), Roma, 155-178.

(2003a), "Parerga III", Habis, 34, 403-409.

(2003b), "Los autores cristianos (siglos II-IV)", Marco Ulpio Trajano. Emperador de Roma. Documentos y fuentes para el estudio de su reinado (J.C. Saquete y J. González Fernández, Coords.), Sevilla, 281-302.

González del Campo, G. (2009), "Trajano en la literatura de corte de Teodosio y Justiniano", Talia Dixit, 4, 43-71.
González Fernández, J. (2000), "Reflexiones en torno a la cronología de las campañas párticas de Trajano", Trajano, emperador de Roma (J. González Fernández, Ed.). Roma, 203-226. (2003), "La correspondencia entre Trajano y Plinio", Marco Ulpio Trajano. Emperador de Roma. Documentos y fuentes para el estudio de su reinado (J.C. Saquete y J. González Fernández, Coords.), Sevilla, 13-75.

González Román, C., (2000), "El proceso de Caecilius Classicus, procónsul de la Bética, a comienzos del reinado de Trajano", Trajano, emperador de Roma (J. González Fernández, Ed.), Roma,179-202.

(2004): “Trajano. Optimus Princeps: a propósito de los alimenta", Trajano óptimo príncipe: de Itálica a la corte de los Césares (J. González Fernández, Coord.), Ciclo de conferencias Centro Cultural El Monte, Sevilla, 173-205.

Downey, Gl. (1955), "Constantine the Rhodian, his Life and Writings", Late-Classical and medioeval Studies in honor of A.M. Friend, Princeton, 214-221.

Grenfell, B., Hunt, A. y Hogarth, D. (1900), Fayum towms and their Papyri, London.

(1920), The Oxyrhynchus Papyri, Cornell.

Hidalgo de la Vega, Mª . J. (1995), El intelectual, la realeza y el poder político en el Imperio Romano, Salamanca.

(2012), Las emperatrices romanas. Sueños de púrpura y poder oculto. Salamanca.

Hölzner, J. (2008), San Pablo. Heraldo de Cristo. Barcelona.

Juliano (1982a), Leyes, Edición de J. García Blanco y P. Jiménez Gazapo, Madrid.

(1982b): Juliano. Discursos VI-XII,. Edición de García Blanco, Madrid.

La Regina, A. (1997), "Le guerre daciche, Roma, il foro", I Daci, Catálogo de la Exposición coordinada por G. Arbone Popescu, Milano, 117-135.

Labruna, L. (1962), “Mandata e Litterae”, Labeo $8 / 2,264-270$.

Lago Marín, J. I., (2008), Trajano: las campañas de un emperador hispano, Almena Ediciones, Madrid.

León Alonso, P. (1988), El Traianeum de Italica, Sevilla.

López Barja de Quiroga, P. y Lomas Salmonte, F.J. (2004), Historia de Roma, Madrid.

López-Cañete, D. (2003), "Plinio. El Panegírico de Trajano”, Marco Ulpio Trajano. Emperador 
de Roma. Documentos y fuentes para el estudio de su reinado reinado (J.C. Saquete y J. González Fernández, Coords.), Sevilla, 87-230.

Mangas Manjarrés, J. (2004), "Trajano y las fronteras del Imperio", Trajano óptimo príncipe: de Italica a la corte de los Césares (J. González Fernández, Coord.), Ciclo de conferencias Centro Cultural El Monte, Sevilla, 141-172.

Manners, R. (1997), "Constructing the image of city: the representation of Constantinopla in Christopher Buondelmonti's Liber Insularum Archipielagi", Annals of the Association of Amerocan Geographer, 87/1, 72-102.

Maravall, J.A. (1986), Antiguos y Modernos, Madrid.

Marrou, H.I. (1932), "Le vie intelectuelle au Forum de Trajan et au Forum d'Auguste”, Mélanges de l'École française de Rome, XLIX, 93-110.

Mattingly, H. (1976), Coins of the Roman Empire in the Bristih Museum, Vol. III, London.

Melucco, A. (2000), "L'Arco di Adriano e il riuso di Costantino", Adriano, architettura e progetto, Roma, 113-130.

Montero, S. (2000), "Trajano y la adivinación tradicional”, Trajano y la Adivinación, Gerión Anejos IV, Madrid, 25-40.

Moreno Soldevilla, R., (2010), G. Plinio Cecilio Segundo. Plinio el Joven. Panegírico de Trajano, Madrid.

Motraye, A. de la (1727), Voyages en Europe, Asie et Afrique, La Haya.

Nathan, G. y McMahon, R. (2000), "Trajan Decius (249-251 d. C.)” , An Online Ecyclopdia of Roman Emperors, www. Roman-emperors.org/ decius.htm, Consulta 15 de marzo de 2016.

Paris, G. (1878), La Légende de Trajan, París.

Plinio Cecilio Segundo el Joven, C. (2010), Panegírico de Trajano, edición a cargo de $\mathrm{R}$. Moreno Soldevilla, Madrid.

(2015) Epistularum Libri Decem, www.perseus.tufts.edu. Consulta 2 de febrero de 2015.

Posadas, J.L. (1996-1997), “Tópicos sobre mujeres en la literatura de época de Trajano” Arx, 2-3, 173-179.

Settis, S. (1984), "La Colonna Traiana”, Revista de Arte y Cultura de la Imagen, 23, 68-106 (1988): "La Colonna", La Colonna Traiana (S. Settis, A. La Regina y G. Agosti, Coords.), Roma, 5-248.

Seroux d'Agincourt, J.B.L. (1823), Historie del'Art par les Monuments depuis sa décadence au
IVe jusqu'à son renouvellement au XVIe, $\mathrm{Pa}-$ ris.

Soria Molina, D. (2015), "Arabia Petrea de reino cliente a provincia romana (63 a. C. al $106 \mathrm{~d}$. C.)", Poder Centrao y Poder Local: dos realidades paralelas en la órbita política roma$n a$, Monografías y Estudios de la Antigüedad Griega y Romana, 45, 313-332.

Schmitz, M. (2005), The Dacian threat, 101-106 $A D$. Armidale, Caeros Publishing, New South Wales.

Syme, R. (1958), Tacitus. Oxford.

Taddei, A. (2009), "La colonna di Arcadio a Costantinopoli profilo storico di un monumento attraverso le fonti documentarie dalle origini all'Età moderna”, Nea Rhome, 6, 37-103.

Teja, R. (1990), El cristianismo primitivo en la sociedad romana, Ed. Istmo, Madrid.

(1993) “Trajano y los cristianos”, Imp. Caes. Nerva Traianus Aug. (J. González Fernández, Ed.), Sevilla, 187-204.

(2000): "Conquirendi non sunt: Trajano, Plinio y los cristianos", Trajano, emperador de Roma (J. González Fernández, Ed), Roma, 451474.

Torelli, M. (1993), “Arcus Marci Aureli”, Lexicon Topographicum Urbis Romae, I, 98-99.

Vallejo Girvés, M. (1997), "Tradiciones y pervivencias paganas en el Imperio Bizantino: el posicionamiento de Justiniano", La Tradición en la Antigüedad Tardía (J.M ${ }^{\mathrm{a}}$ Blázquez Martínez, A. González Blanco y R. González Fernández, Eds.), Antigüedad y Cristianismo, XIV, 217228.

Verdugo Santos, J. (2011), “Aulea premuntur. El Theatrum Balbi de Gades en la Red de Espacios Culturales de Andalucía", El Theatrum Balbi de Gades (D. Bernal y A. Arevalo, Eds.), Cádiz, 83-104.

(2015), "La formación del concepto de tutela del patrimonio histórico en la Antigüedad: Monumento y objeto arqueológico en el Derecho Romano", Revista de Derecho romano, 25, 1-56. (2017a), "El interés por el pasado en la Antigüedad”, Onoba, Revista de Arqueología y Antigüedad, 5, 195-218.

(2017b), "La reinterpretación cristiana de los monumentos de la Antigüedad en la Roma de Sixto V (1585-1590)", Archivo Español de Arqueología, 90, 53-76. 